\title{
A direct requirement for Hedgehog signaling for normal specification of all ventral progenitor domains in the presumptive mammalian spinal cord
}

\author{
Mark Wijgerde, ${ }^{1,2,3}$ Jill A. McMahon, ${ }^{1,3}$ Michael Rule, ${ }^{1}$ and Andrew P. McMahon ${ }^{1,4}$ \\ ${ }^{1}$ Department of Molecular and Cellular Biology, The Biolabs, Harvard University, Cambridge, Massachusetts 02138, USA
}

\begin{abstract}
The hedgehog signaling pathway organizes the developing ventral neural tube by establishing distinct neural progenitor fates along the dorsoventral axis. Smoothened (Smo) is essential for all Hedgehog (Hh) signaling, and genetic inactivation of Smo cells autonomously blocks the ability of cells to transduce the Hh signal. Using a chimeric approach, we examined the behavior of Smo null mutant neural progenitor cells in the developing vertebrate spinal cord, and we show that direct $\mathrm{Hh}$ signaling is essential for the specification of all ventral progenitor populations. Further, Hh signaling extends into the dorsal half of the spinal cord including the intermediate Dbx expression domain. Surprisingly, in the absence of Sonic hedgehog (Shh), we observe the presence of a Smo-dependent Hh signaling activity operating in the ventral half of the spinal cord that most likely reflects Indian hedgehog (Ihh) signaling originating from the underlying gut endoderm. Comparative studies of Shh, Smo, and Gli3 single and compound mutants reveal that Hh signaling acts in part to specify neural cell identity by counteracting the repressive action of Gli3 on p0, p1, p2, and pMN formation. However, whereas these cell identities are restored in Gli3/Smo compound mutants, correct stratification of the rescued ventral cell types is lost. Thus, Hh signaling is essential for organizing ventral cell pattern, possibly through the control of differential cell affinities.
\end{abstract}

[Keywords: Smoothened; neural tube; patterning; Gli3; cell affinity; Mouse]

Received July 22, 2002; revised version accepted September 23, 2002.

The Hedgehog $(\mathrm{Hh})$ signaling pathway, initially described for its organizing activity in patterning the Drosophila embryonic epidermis, plays many distinct roles in the development of Drosophila and vertebrate embryos (Hatini and Dinardio 2001; Ingham and McMahon 2001; McMahon et al. 2002). Further, misregulation of Hh signaling in humans is associated with congenital malformations of the central nervous system (CNS; spina bifida, holoprosencephaly), head (cleft palate), and limb (syn- and polydactyly) and with a predisposition for developing a variety of tumors of the skin (basal cell carcinoma) and CNS (medulloblastoma, glioblastoma; Ming et al. 1998; Hahn et al. 1999; McMahon et al. 2002). Given the importance of this pathway, there is considerable interest in understanding the basic properties and actions of $\mathrm{Hh}$ ligands; how an active hedgehog signal is

\footnotetext{
${ }^{2}$ Present address: Department of Reproduction and Development, Erasmus MC, Erasmus University Rotterdam, P.O. Box 1738, 3000DR, Rotterdam, The Netherlands.

${ }^{3}$ These authors contributed equally to this work.

${ }^{4}$ Corresponding author.

E-MAIL amcmahon@mcb.harvard.edu; FAX (617) 496-3763.

Article and publication are at http://www.genesdev.org/cgi/doi/10.1101/ gad.1025702.
}

produced, moved, received, and transduced to give an appropriate response in a specific target tissue.

A single Drosophila hedgehog gene has three mammalian counterparts: Sonic hedgehog (Shh), Indian hedgehog (Ihh), and Desert hedgehog (Dhh; Echelard et al. 1993). Shh, the most extensively studied of the three, is involved in developmental patterning of many organs including the spinal cord, the focus of the present study (for review, see Jessell 2000; Briscoe and Ericson 2001; McMahon et al. 2002). The active, secreted form of Hh proteins is produced through an autocatalytic cleavage of a precursor protein $(\mathrm{Shh}, 46 \mathrm{kD})$ releasing an active $\mathrm{N}$ terminal fragment $\left(\mathrm{N}-\mathrm{Shh}_{\mathrm{p}}, 19 \mathrm{kD}\right)$, which is modified by the covalent addition of a cholesterol moiety at its $\mathrm{C}$ terminus (Lee et al. 1994; Bumcrot et al. 1995; Porter et al. $1995,1996 a, b)$. In addition, Hh proteins are palmitoylated on a conserved N-terminal Cys-residue that immediately follows the signal peptide recognition sequence (Pepinsky et al. 1998; Chamoun et al. 2001). As a result of lipid modification, $\mathrm{N}-\mathrm{Shh}_{\mathrm{p}}$ is largely cell-associated, presumably by attachment to the lipid bilayer (Rietveld et al. 1999). Hh ligands are bound by a 12-transmembrane protein receptor, Patched1 (Ptc1; Marigo et al. 1996; Stone et al. 1996). In the absence of Hh-ligand, Ptc1 
inhibits the activity of the seven-pass membrane protein Smoothened (Smo), blocking active signal transduction. The exact mechanism of Ptc-mediated silencing of Smo activity is unclear. However, derepression of Ptc on binding of Hh in Drosophila is accompanied by the stabilization and accumulation of phosphorylated forms of Smo at the cell membrane (Denef et al. 2000; Ingham et al. 2000; Strutt et al. 2001). Further, the identification of a mutant in Rab23, a member of a family of proteins associated with membrane trafficking that leads to Shhindependent activation of Shh targets, implicates trafficking processes in Smo activation (Eggenschwiler et al. 2001). Activation or repression of $\mathrm{Hh}$ targets is mediated in Drosophila by a single regulator, Cubitis interruptus (Ci), and in vertebrates three Ci-homologs, Gli1, Gli2, and Gli3, each of which has distinct transcriptional properties and functions (for review, see Ingham and McMahon 2001).

Pattern regulation in the vertebrate neural tube has provided an excellent model for the study of Shh actions. In the vertebrate central nervous system (CNS), the assembly of functional neuronal circuits begins with the generation of distinct classes of neural progenitor populations at specific positions along the anterior-posterior and dorsoventral axes of the developing neural tube (Jessell 2000). This organization is best understood at the spinal cord level, where the unique and partially overlapping patterns of expression of several families of homeodomain-containing transcriptional regulators define five neural progenitor populations in the ventral half of the neural tube. From ventral to dorsal, these are the p3, $\mathrm{pMN}, \mathrm{p} 2, \mathrm{p} 1$, and $\mathrm{p} 0$ progenitors. $\mathrm{pMN}$ progenitors later give rise to motorneurons, and $\mathrm{p} 3, \mathrm{p} 2, \mathrm{p} 1$, and $\mathrm{p} 0$ progenitors give rise to $\mathrm{v} 3, \mathrm{v} 2, \mathrm{v} 1$, and v0 interneurons, respectively (for review, see Jessell 2000; Briscoe and Ericson 2001; McMahon et al. 2002).

In the presumptive spinal cord region, Shh is initially secreted by the midline axial mesoderm, the notochord, which underlies the ventral midline of the neural plate, and later from the ventral midline of the neural tube itself, the floor plate, which lies immediately adjacent to the $\mathrm{p} 3$ progenitor domain. Shh is sufficient in vitro for the induction of all five progenitor populations. Moreover, the concentration threshold required for each induction mirrors the position of progenitor pools within the neural tube; progressively higher concentrations are required for the induction of progenitor domains moving towards the source of $\mathrm{Hh}$ ligand at the ventral midline. Expression of the homeodomain factors that identify a distinct ventral progenitor domain is modulated by Shh signaling: Class I genes, which include $P a x 7, D b x 1$, $D b x 2$, Irx3, and Pax6, are repressed, whereas Class II genes, such as $N k x 2.2$ and $N k \times 6.1$, are activated in response to Shh signaling. Further, cross-repressive interactions by homeodomain factors in adjacent domains most likely refine and maintain progenitor domains and, as cells differentiate, the homeodomain proteins direct neuronal subtype identity (Briscoe et al. 2000; Briscoe and Ericson 2001).

In short, these data are consistent with a model in which Shh acts as a long-range morphogen, acting directly over the entire ventral neural tube to establish distinct spatial domains of homeodomain factors at distinct concentration thresholds. The homeodomain code thereby established within a progenitor cell subsequently dictates that cell's neuronal fate within the ventral spinal cord. However, the data are also consistent with a second hypothesis, that Shh-dependent, secondary signaling mechanisms might also play some part in the patterning process. Indeed, retinoic acid has been shown to induce p0 and p1 progenitors (Pierani et al. 1999). Further, p0, p1, and to a lesser extent p2 progenitors form in Shh mutants, suggesting that induction of these most dorsally located ventral progenitor cell identities are specified by a Hh-independent mechanism (Pierani et al. 1999; Litingtung and Chiang 2000; this study). Hh-induced signaling relays are known to control growth and pattern in Drosophila imaginal discs (for reviews, see Ingham and McMahon 2001; McMahon et al. 2002). To address the direct role of Hh signaling in patterning the vertebrate neural tube, we compared the cell fates adopted by Smo-/-(Smo mutant) and Smo+/- (phenotypically wild-type) cells, at specific positions in the developing mouse spinal cord. By performing this analysis, and examining spinal cord pattering in Shh, Smo, and Gli3 single and compound mutants, we found support for a model in which direct Hh signaling is essential for the specification of all ventral progenitor identities, acting in part to overcome Gli3-mediated repression of these cell states which occurs in the absence of a Hhsignaling input.

\section{Results}

Behavior of Smo-/- cells in the developing spinal cord of chimeric embryos

In order to study the behavior of Smo null mutant cells (Smo-/-) in the developing spinal cord, we generated chimeric mouse embryos composed of wild-type and Smo-/- mutant cells. The Smo null allele was reported elsewhere (Zhang et al. 2001). In one approach (Fig. 1A), we derived two Smo-/- and three Smo+/- embryo stem (ES) cell lines from blastocyst outgrowths. Each of these lines also carried a Rosa26lacZ reporter allele, which allows the identification of all descendants of a given ES cell line following their injection into a host blastocyst, and subsequent implantation and development into chimeric embryos. Chimeric embryos in which the experimental cells were either wild-type or heterozygous for the Smo null allele (Smo+/-) served as a chimeric control population, and no detectable differences were observed between these two distinct genotypes. In a second approach (Fig. 1A), we used morula-morula aggregates between wild-type embryos and embryos derived from a Smo+/-;Rosa26lacZ compound heterozygous intercross to generate chimeras. At collection, tailbud regions from embryos were removed, and fibroblast cultures were established under G418 selection to facilitate PCR-mediated identification of the genotype of the cells derived 
ES cell injection

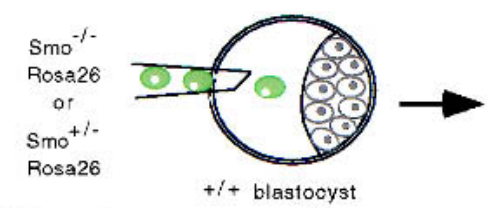

Morula aggregation
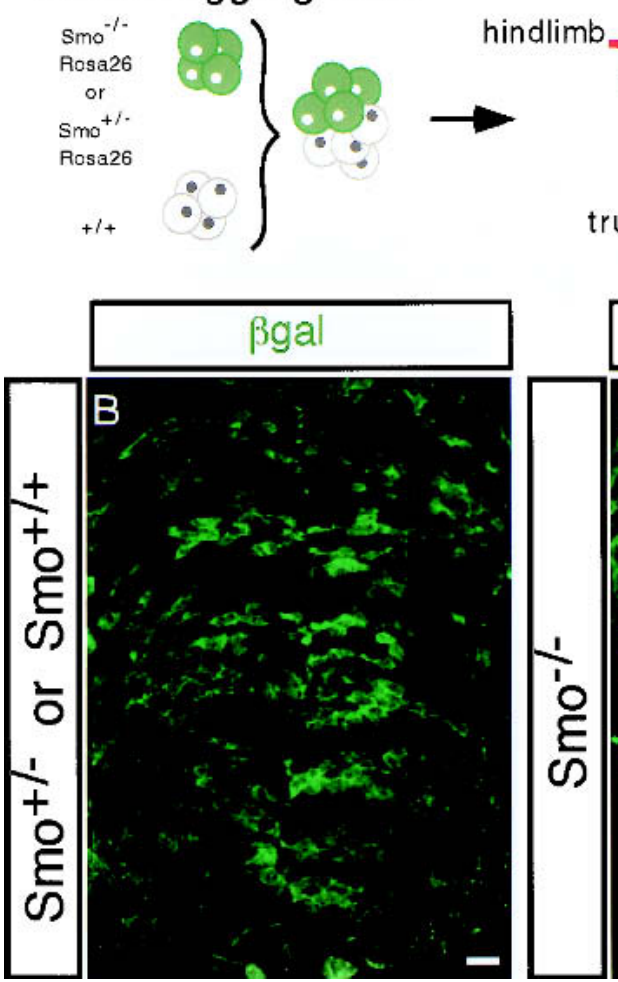

$\mathrm{B}$

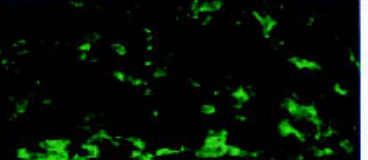

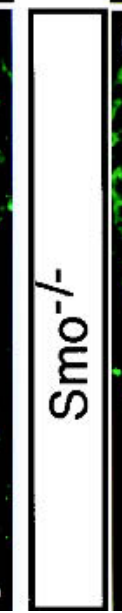

\section{$10.5 \mathrm{dpc}$}

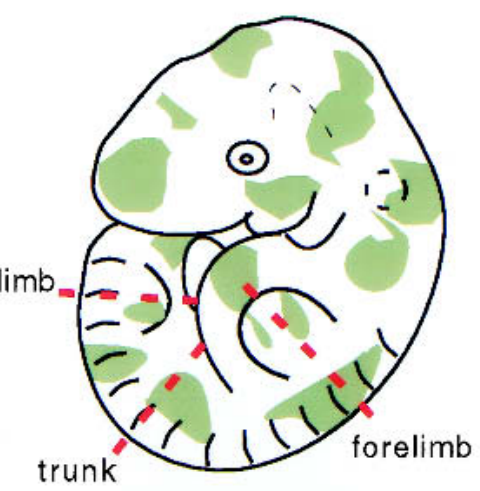

trunk

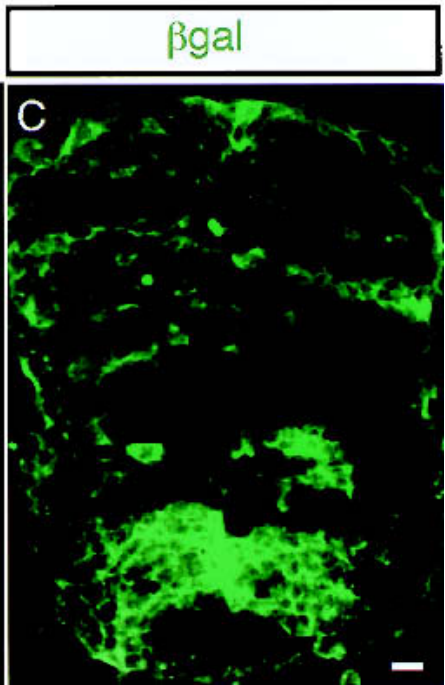

Figure 1. Generation of ROSA26 genetically marked Smo mutant chimeric mouse embryos. (A) ES cell injection into blastocyst and aggregation of morula stage embryos were performed to generate chimeric mouse embryos. Experimental cells are colored green, which indicates Escherichia coli cytoplasmic $\beta$-Galactosidase ( $\beta$-Gal) provided by the ROSA26 insertion of a $\beta$-geo allele (Zambrowicz et al. 1997). Chimeric embryos were harvested at $10.5 \mathrm{dpc}$ from foster mothers and were examined at forelimb, trunk, and hindlimb levels. $(B, C)$ Distribution of $\mathrm{Smo+} /-$ and Smo-/- cells (green) in a section of a 10.5-dpc spinal cord using fluorescently labeled antibodies to visualize $\beta$-Gal proteins (green). Bar, $20 \mu \mathrm{m}$.

from the Smo mutant intercross (data not shown). The only G418-resistant cell types are derived from the ES cells where the $\beta$-geo (Neomycin phosphotoransferase/ $\beta$-galactosidase fusion) insertion at the Rosa26 locus confers G418 resistance on all ES cell descendants. Similar results were obtained when ES-embryo and embryoembryo chimeras were compared, demonstrating that the ES lines behaved normally. For brevity we only show data obtained with ES-embryo chimeras.

To distinguish the genetically modified ES-cells from wild-type host cells in the chimera, expression of the ubiquitously expressed lacZ reporter gene in relevant cells was assessed by immunofluorescent detection of cytoplasmic $\beta$-Galactosidase ( $\beta$-Gal) in the neural tube at forelimb levels, the principal focus of this study (Fig. 1B,C). Although $S m o-/ S m o-$ embryos do not survive beyond 8.75-9.0 dpc (Zhang et al. 2001), Smo-/Smo- cells show a broad distribution throughout the neural tube of chimeras at $10.5 \mathrm{dpc}$. However, whereas wild-type and $\mathrm{Smo}+$ - cells show a highly mosaic distribution (Fig. 1B) along the dorsoventral (DV) axis, Smo-/- cells appear to form tight clusters, thereby minimizing their contact with neighboring wild-type cells (Fig. 1C). The apparent aggregation of Smo-/- cells was more pronounced in the ventral half of Smo-/- chimeric neural tubes (Fig. 1C).

Specification of dorsal cell fates in the presumptive spinal cord is thought to be independent of Shh signaling, mediated in large part by members of the TGF- $\beta$ superfamily of signaling proteins (for review, see Lee and Jessell 1999/. Consistent with this view, Smo+/- and Smo-/- cells showed an equivalent contribution to the dorsal midline roofplate and Math1-, D1a/b (LH2a/b)-, and D2 (Isl1/2)-producing dorsal neural progenitors (Fig. 2A-D; data not shown).

In contrast to $\mathrm{Smo} /$ - cells, Smo-/- cells only rarely contributed to the ventral-medial cells of the floor plate, a region of specialized support cells that is induced in response to primary Shh signal production by the notochord (Figs. 1C, 2E-L). The occasional Smo-/- cell within the floor plate failed to activate either Shh or HNF3 $\beta$ (arrowheads in Fig. 2J, $\mathrm{K}_{\text {; }}$ data not shown), whereas adjacent wild-type cells showed normal expression of these floor plate markers (Fig. 2J-L). Thus, as expected, there is an absolute requirement for Hh-signal responsiveness to specify floor plate cell identities. As a consequence, the production of Shh by floor plate cells, a 

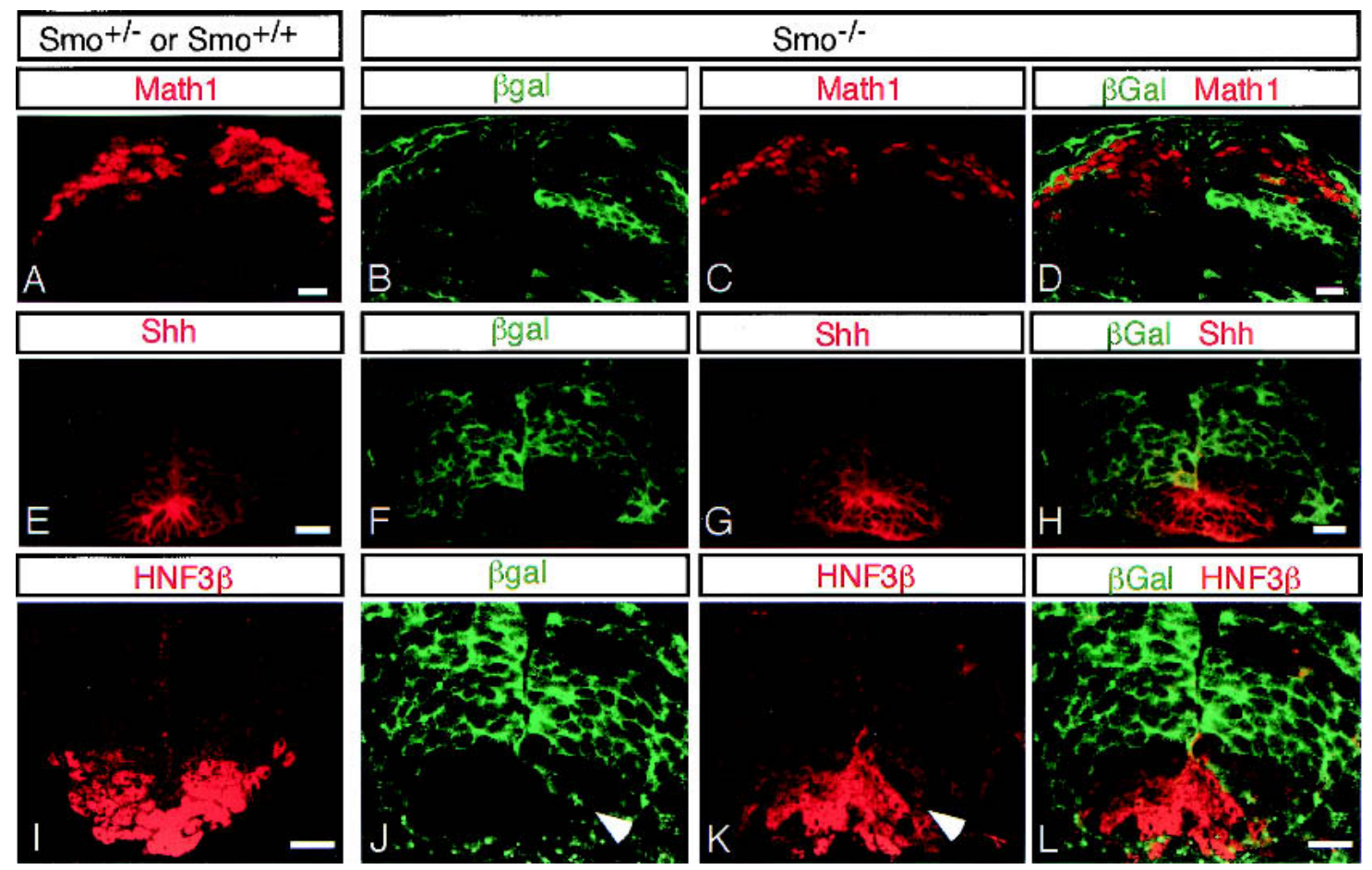

Figure 2. Smo-/- cells (green) can generate dorsal neurons but are unable to give rise to floor plate cell identities. Sections through the neural tube of control (Smo+/+ or Smo+/-; $A, E, I)$ and experimental (Smo-/-; B-D,F-H,J-L) chimeras. Normal Math1 immunofluorescence in the dorsal spinal cord of a 10.5-dpc wild-type and Smo+/- chimeric mouse embryo $(A)$, and a Smo-/- chimeric mouse embryo $(B-D)$. Shh immunofluorescence in the floor plate of a wild-type and $S m o+/-$ chimeric spinal cord $(E)$, and in a $S m o-/-$ chimeric spinal cord $(F-H)$. HNF3 $\beta$ immunofluorescence in the ventral-most region of a wild-type and $S m o+/-$ chimeric spinal cord $(I)$, and a Smo-/- chimeric spinal cord $(J-L)$. Arrowhead indicates a Smo-/- cell that is located within the floor plate domain but does not express HNF3ß. Bar, $20 \mu \mathrm{m}$.

secondary source of Shh to the developing neural tube, was largely unaffected in Smo-/- chimeras. Therefore, there was no significant alteration in the function of the floor plate as a signaling center in Smo-/- chimeras (Fig. 2E-L).

\section{Smo-/- cells in the ventral spinal cord obtain} dorsal characteristics

To determine whether Smo-/- mutant cells alter the response of ventral neural precursor cells to Shh signaling as expected, we tested the expression of the Shh target genes, Ptch1 and Gli3. Ptch1 encodes the Shh receptor, and its expression is upregulated in response to Shh signaling (Goodrich et al. 1996; Marigo and Tabin 1996). In a wild-type neural tube, Shh signaling results in graded expression of Ptch1 mRNA throughout the ventral half of the spinal cord, with the highest levels ventrally decreasing to low levels dorsally (Goodrich et al. 1996). To examine the response of Smo-/- cells in the neural tube of chimeric embryos, we compared the distribution of $\beta$-Gal-producing cells to the levels of Ptch1 expression in adjacent sections. In the neural tube of $\mathrm{Smo+} /$ - chimeras, Ptch1 expression was unaltered (Fig. $3 \mathrm{~A}, \mathrm{~B})$. However in the spinal cord of Smo-/- chimeras, Ptch1 expression was reduced in ventral regions com- prised of Smo-/- cells, whereas the response in adjacent wild-type cells was either similar to that in $\mathrm{Smo}+/-$ chimeras, or slightly elevated (brackets in Fig. 3C,D). Gli3 encodes a member of the Gli family of transcriptional effectors of the Hh signaling response, which plays a role in the suppression of the pMN fate in Shh mutants (Litingtung and Chiang 2000; Wang et al. 2000). In the wildtype neural tube, Gli3 expression mirrors that of Ptch1, as Gli3 is repressed by Shh signaling (Fig. 3E,F). In contrast, we observe ectopic expression of Gli3 in ventrally located Smo-/- cells in Smo-/- chimeras (Fig. 3G,H). The failure of Smo-/- cells to activate Ptch1 and repress Gli3 indicates that Smo-/- cells were unable to respond to Hh signals.

\section{Smo is required for the specification of all ventral neural progenitor populations}

In the ventral spinal cord, a combinatorial code of transcriptional regulators, predominantly homeodomain proteins, define and specify five molecularly distinct classes of mitotically active neural progenitor cell types, and the postmitotic neural precursor, which they subsequently generate (summarized in Fig. 4A; modified from Briscoe et al. 2000; Briscoe and Ericson 2001). The three ventralmost neural progenitor pools, $\mathrm{p} 3, \mathrm{pMN}$, and $\mathrm{p} 2$, 
CNS patterning requires direct hedgehog signaling

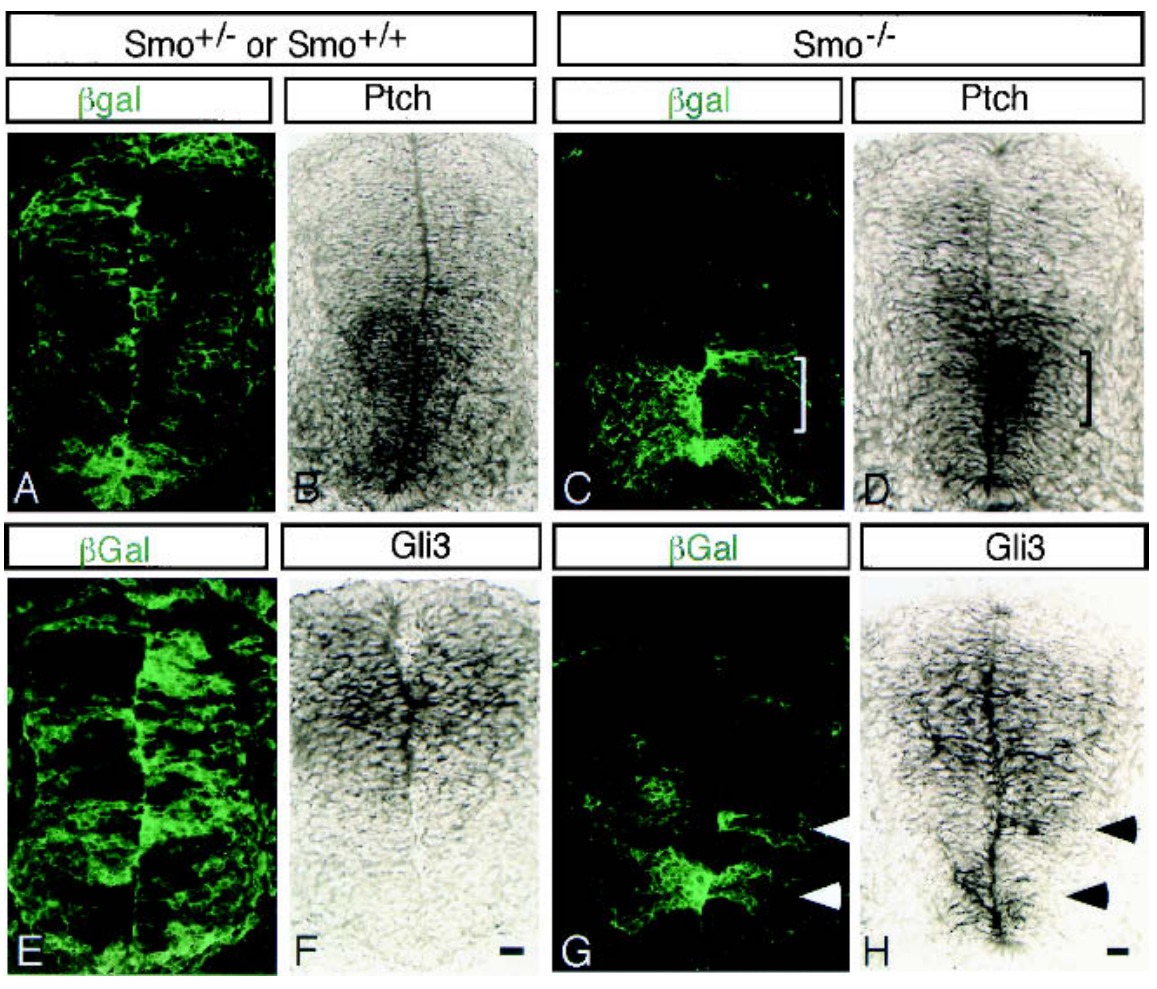

Figure 3. Smo-/- cells in the ventral half of the spinal cord fail to respond to Hh signaling. Adjacent sections were examined to compare the distribution of Smo-/- cells in the chimera neural tube (green in $A, C, E, G)$ to Ptch1 $(B, D)$ and Gli3 $(F, H)$ mRNA expression. In wildtype or $\mathrm{Smo}+/$ - chimeric spinal cords, Ptch1 expression shows a normal graded distribution $(B)$ and Gli3 expression is dorsally restricted $(F)$. Smo-/- cells in the ventral spinal cord express low levels of Ptch1 $(D)$ and ectopically express Gli3 (arrowheads in $G, H$ ), whereas adjacent ventral wild-type cells express normal levels of Ptch1 (marked by bracketing in $C)$ and low levels of Gli3 (H). Bar, $20 \mu \mathrm{m}$. can be identified by antibodies that recognize $\mathrm{Nkx} 6.1$ and Nkx2.2, Nkx6.1 and Olig2, and Nkx6.1 and Irx3, respectively (Briscoe et al. 1999; Sander et al. 2000; Fu et al. 2002). Nkx6.1, Nkx2.2, and Olig2 are Class II response genes, activated by Shh signaling. Although Smo-/- cells contribute to each of these regions, no Smo-/- cells are Nkx2.2-, Nkx6.1-, or Olig2-positive (Fig. 4B-M). Thus, the specification of each of these three ventral neuroprogenitor populations shows an absolute requirement for $\mathrm{Hh}$ signaling.

We next examined markers of the $\mathrm{p} 1$ and $\mathrm{p} 0$ progenitor populations, which can be recognized by the presence of Dbx2, or both Dbx1 and Dbx2, respectively. When Smo-/- cells are present within the normal Dbx domains in the intermediate region of the spinal cord, they fail to express both Dbxl (arrowheads in Fig. 5B,C) and Dbx2 (arrowheads in Fig. 5F,G). This is true even in positions where the cellular distribution overlaps that of the general dorsal factor Pax7, in cells that are thought to represent the dorsal p5 (Dp5) progenitor population (see Figs. 4A, 5F-H). Surprisingly, both Dbx1 and Dbx2 were ectopically active in Smo-/- cells in more ventral regions of the neural tube. Thus, there is a requirement for Hh signaling in the normal induction of ventral p1 and p0 progenitors, and dorsal p5 progenitors, at intermediate positions within the neural tube. In addition, there is a requirement for Hh signaling to prevent ectopic specification of some of these fates in more ventral positions. Irx3 and Pax6 both overlap with Dbx1 and Dbx2, though their expression extends to more ventral positions (Fig. 4A). Like $D b x 1$ and $D b x 2$, Irx3 and Pax6 are Class I genes whose expression appears to be repressed in re- sponse to Shh signaling, and both were also ectopically expressed by $\mathrm{Smo}-/$ - cells below their normal ventral expression limits (Fig. 5I-P). However, whereas Smo was required for the normal production of Pax6 near the DV boundary (arrowheads in Fig. 5N,O), Irx3 production in the same region was unaffected in Smo-/- cells (Fig. 5J-L).

To more precisely map the extent of the intermediate domain in which Smo-/- cells fail to express Pax6, we used triple immunofluorescence to detect Pax6, $\beta$-Gal, and either Dbx1 or Dbx2. These triple staining experiments demonstrated that the failure of Smo-/- cells to produce normal levels of Pax6 was limited to and extends just dorsal and ventral of the Dbxl domain, an intermediate region characterized by the presence of Dbx2-positive cells (arrowheads in Fig. 5R-T; data not shown).

\section{Smo-/- cells have an altered ventral neuronal identity}

To determine whether the altered expression of markers of ventral progenitor populations represents a neural switch in neural progenitor identity, we determined whether there is a corresponding change in the generation of specific neuronal subtypes by the expression of markers of ventral neural precursors. Smo-/- cells were unable to generate motor neuron precursors (MNR2; Fig. 6A-D; Islet1/2; data not shown), or v2 (Chox10; data not shown), v1 (En1; Fig. 5E-H), or v0 (Evx1/2; Fig. 6I-L) interneuron precursors in their normal positions. However, the presence of an occasional Evx1/2-positive cell in the most ventrally located Smo-/- cells, adjacent to 
Wijgerde et al.

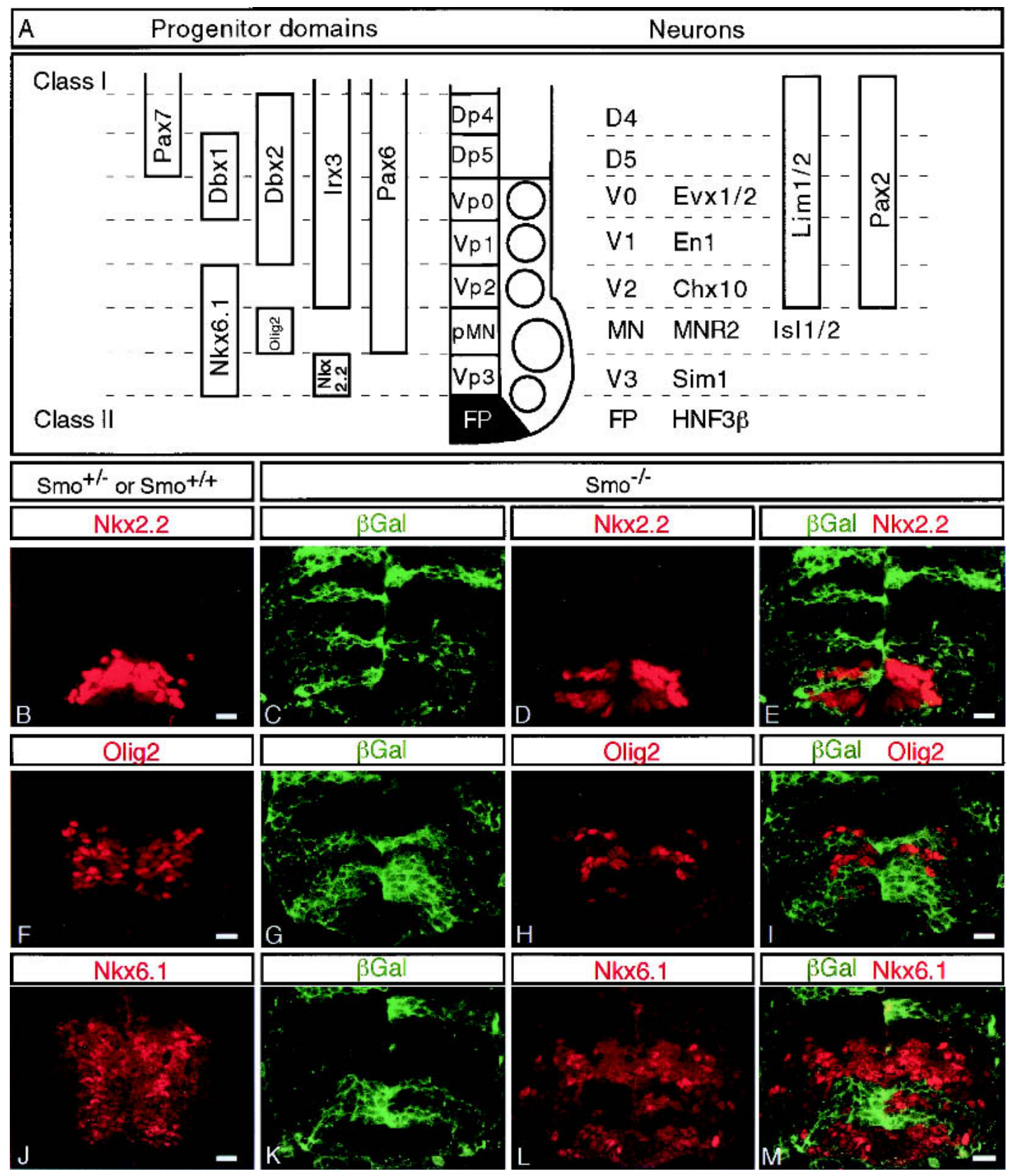

Figure 4. Smo-/- cells fail to express Class II homeodomain proteins. (A) Summary of the expression domains of the different marker genes and the relationship between progenitor domains and their neural progeny (adapted from Briscoe et al. 2000, 2001). Sections through the neural tube of control $(S \mathrm{mo}+/+$ and $S \mathrm{mo}+/-; B, F, J)$ or experimental $(S m o-/-; C-E, G-I, K-M)$ chimeras. $(B, F, J)$ Normal expression patterns of Nkx2.2(B), Olig2 (F), and Nkx6.1 (J). Smo-/- cells (green) fail to express the Class II marker genes Nkx2.2 (C-E), Olig2 $(G-I)$, and Nkx6.1 $(K-M)$. Bar, $20 \mu \mathrm{m}$.

the floor plate, indicates that ectopic v0 interneuron precursors can arise in more ventral regions of the neural tube in the absence of direct Hh signaling (arrowheads in Fig. 6K,L). Further, we also observed ventral cells ectopically producing Lim1/2 (Fig. 6M-P) and Pax2 (Fig. 6Q$\mathrm{T})$, regulatory factors that are normally restricted to v0 and v1 precursors, as well as some more dorsal precursors including those derived from dorsal p5 progenitors (Fig. 4A; Burrill et al. 1997).
Taken together these data indicate that Hh signaling is required for the normal specification of all ventral precursor populations, and for the suppression of v0, and possibly other more dorsal neural precursor subtypes in ventral regions of the neural tube. In agreement with this conclusion, we observed that Pax7, whose expression partially overlaps that of Dbxl but extends into more dorsal regions, was expressed at high levels in all ventrally located Smo-/- cells (Fig. 6U-X). Thus, there was 


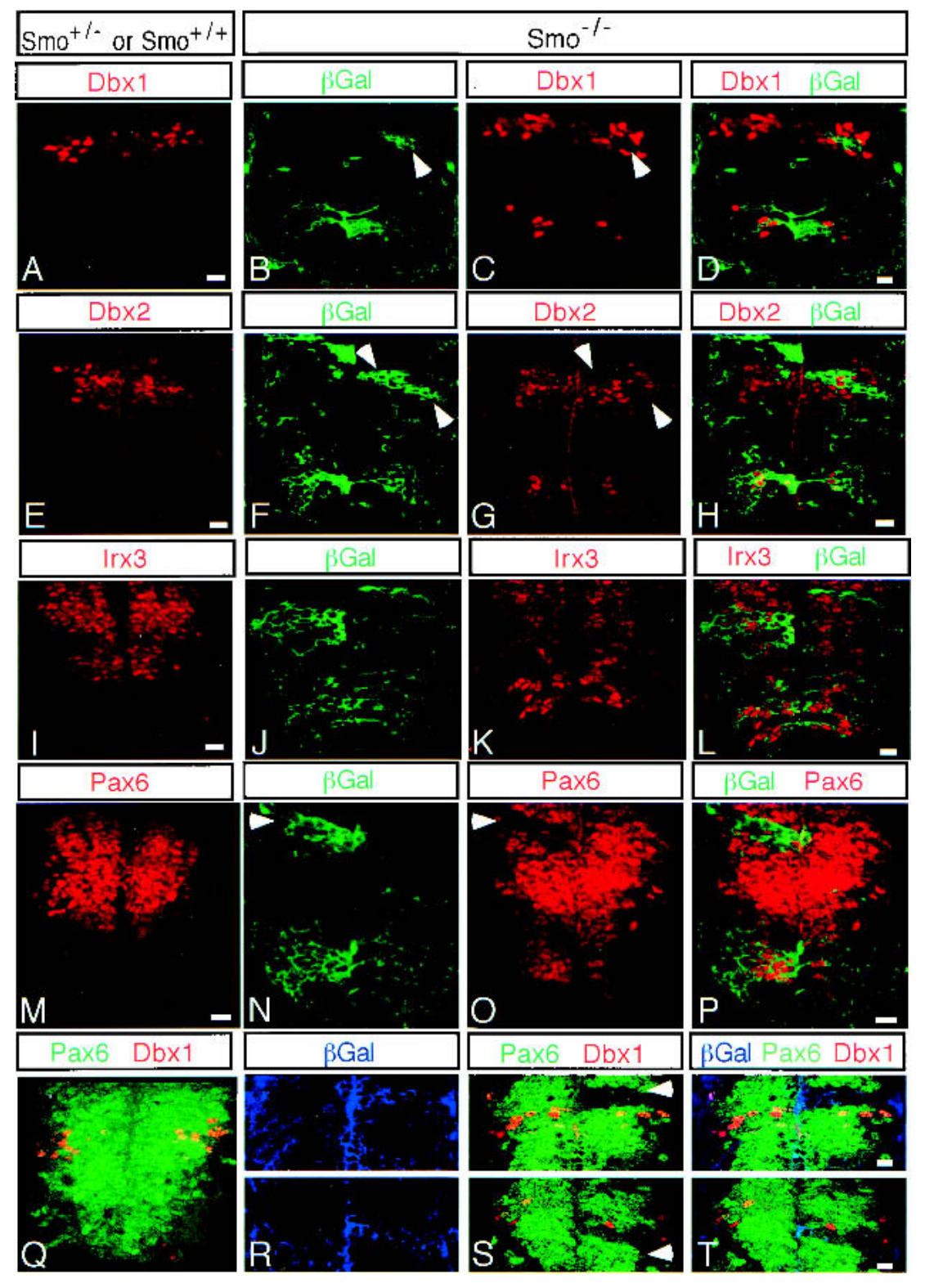

Figure 5. Smo-/- cells ectopically express Class I genes in the ventral spinal cord. Sections through the neural tube of control $(\mathrm{Smo+} /+$ or $\mathrm{Smo+} /-; A, E, I, M, Q)$ and experimental (Smo-/-; B-D,F-H,J-L,N-P,R-T) chimeras. Normal domains of $\operatorname{Dbx} 1(A, Q), \operatorname{Dbx} 2$ $(E)$, Irx3 $(I)$, and Pax6 $(M, Q)$ progenitor cells. Smo-/- cells (green in $B, F, J, N$; blue in $R$ ) ectopically activate expression of $\operatorname{Dbx} 1(C, D)$, $\operatorname{Dbx} 2(G, H)$, Irx3 $(K, L)$, and Pax6 $(O, P)$ in the ventral spinal cord. However, Smo-/- cells fail to express Dbx1 $(B-D), \operatorname{Dbx} 2(F-H)$, and Pax6 $(N-P, R-T)$ in their normal domains in the intermediate region of the spinal cord (see text). Panels $R, S$, and $T$ represent two independent confocal pictures of the intermediate region of the spinal cord of chimeric embryos. Bar, $20 \mu \mathrm{m}$. a cell-autonomous acquisition or retention (see Discussion) of more dorsal fates by ventrally located Smo-/cells. Analysis of sections at several anterior-posterior levels within the presumptive spinal cord (forelimb, trunk, and hindlimb levels) demonstrated that all Smo-/- cells in ventral positions adopted more dorsal identities as described above (data not shown).

\section{Shh-independent Hh signaling in the spinal cord} of Shh-/- embryos

The demonstration that there is a direct requirement for Hh signaling that extends to the p0 progenitor domain, at the dorsal limit of the ventral progenitor population and most likely more dorsally into Dbx2/Pax7-positive progenitors, contrasts with the observation that $\mathrm{Shh}$ mutant embryos generate v0, v1, and occasionally v2 ven- tral interneuron precursors at forelimb levels (Pierani et al. 1999; Litingtung and Chiang 2000). One possible explanation is that the removal of Shh signaling does not abolish all Hh signaling within the neural tube. Ihh is coexpressed with Shh in the underlying gut endoderm, and it is clear that together these two signals play a semiredundant role in patterning other ventral structures, notably somites (Zhang et al. 2001).

Repression of $\mathrm{Pax} 7$ from the medial neural plate is one of the first actions of Shh signaling which occurs at very low (pM) threshold concentration (Ericson et al. 1996). Further, Pax7 was present in all ventrally located Smo-/- cells (see above). However, in the Shh mutant spinal cord, Pax7 was not present in ventral midline cells at forelimb levels, suggesting that these cells may have received a low-level Hh signal (Fig. 7A). These same cells were Dbx1-positive and therefore likely to include p0 
Wijgerde et al.

Figure 6. Smo-/- cells show an altered pattern of neurogenesis in the ventral spinal cord. Sections through the neural tube of control $\left(\mathrm{SmO}_{+} /+\right.$or $\mathrm{Smo}+\mathrm{H}_{-}$; $A, E, I, M, Q, U)$ and experimental (Smo-/-; $B-D, F-H, J-L, N-P, R-T, V-X)$ chimeras. Normal domains of MNR2 $(A), \operatorname{En} 1(E), \operatorname{Evx} 1 / 2$ $(I), \operatorname{Lim} 1 / 2(M), \operatorname{Pax} 2(Q)$, and $\operatorname{Pax} 7(U)$. Smo-/- cells (green) fail to express MNR2 $(B-D)$, En $1(F-H)$, and Evx1/2 $(J-L)$ in their normal domains, whereas Smo-/- cells ectopically express Lim $1 / 2(N-P)$, Pax2 $(R-$ $T), \operatorname{Pax} 7(V-X)$, and occasionally Evx1/2(J$L)$, but not En1 $(F-H)$ in the ventral spinal cord of chimeric embryos. Bar, $20 \mu \mathrm{m}$.
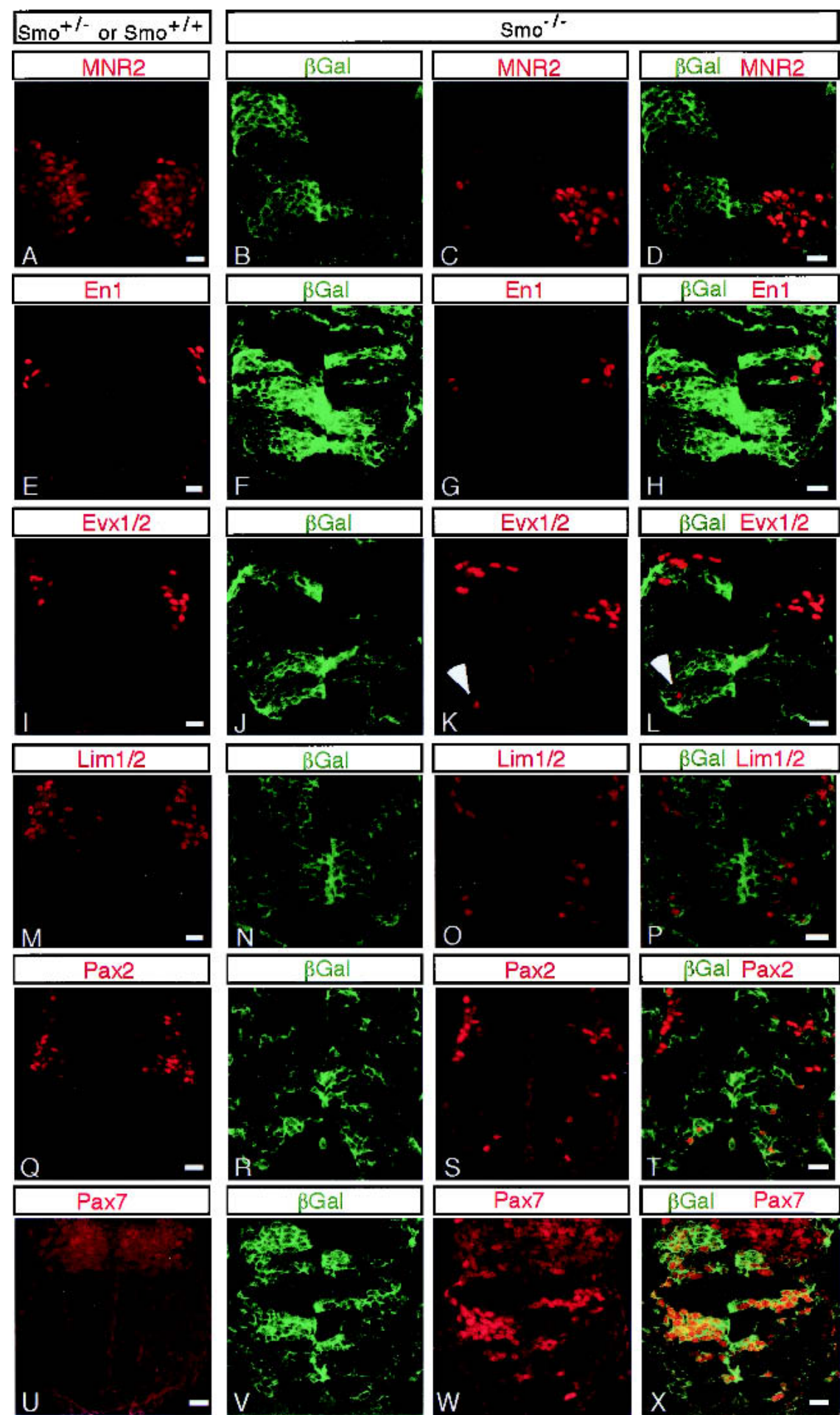

progenitors (Fig. 7A). Indeed, subsequent analysis revealed the Evx1/2 v0 and En1 v1 interneuron precursors were restricted to this same ventral midline domain (Fig. 7B). That a low level of Hh signaling activity remains in the neural tube of Shh mutant embryos was further supported by the observation of a low, graded upregulation of Ptch1 expression in the ventralmost region of the neural tube, where v0 and v1 precursors arise (Fig. 7C).

To extend these findings, we next examined 13-15somite-stage Shh and Smo null mutant embryos for the presence of ventral marker genes. At this stage, Smo mutant embryos have not degenerated; however, their pronounced vascular defects preclude analysis at later stages (Zhang et al. 2001). In contrast to wild-type littermates, no expression of Nkx2.2 or Nkx6.1 was observed in the neural tubes of either Shh or Smo mutant embryos, con- 

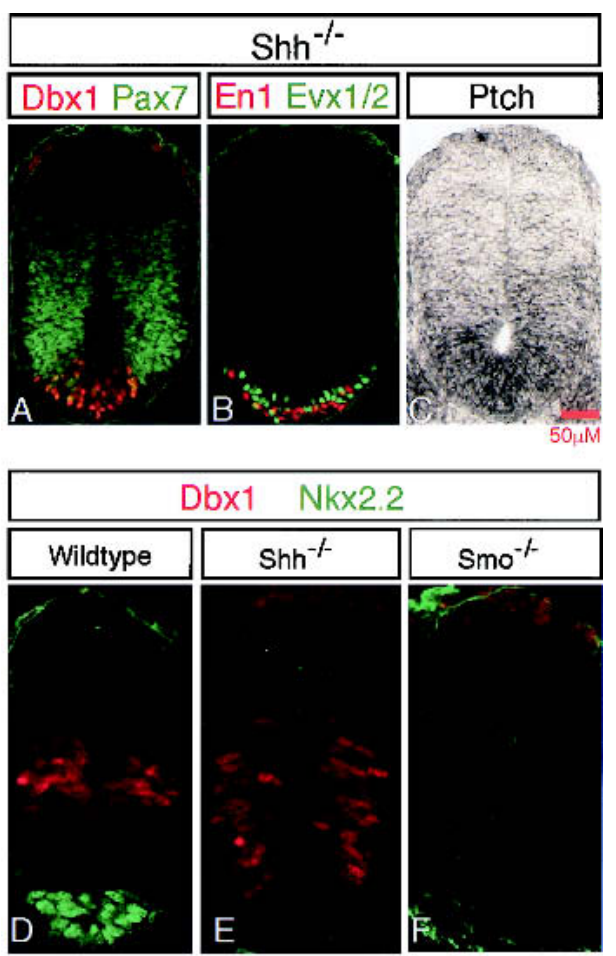

\begin{tabular}{|c|c|c|}
\hline \multicolumn{3}{|c|}{ Dbx1 } \\
\hline Wildtype & $\mathrm{Shh}^{-1-}$ & $\mathrm{Smo}^{-1-}$ \\
\hline
\end{tabular}

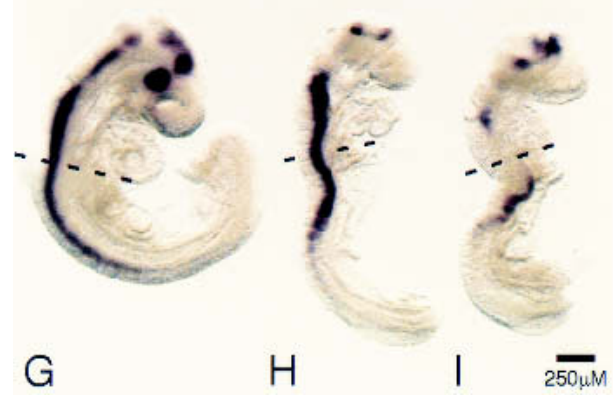

Figure 7. Shh-independent Smo-dependent Hh signaling in the ventral spinal cord of Shh-/- embryos. (A) Pax7 is repressed in the ventral spinal cord of $S h h-/-$ embryos where ventral $\left(\right.$ Pax $\left.{ }^{\text {off }}\right)$ Dbx1-expressing neural progenitor cells, as well as En1and Evx1/2- $(B)$ expressing v0 and v1 neurons are generated. $(C)$ A low graded level of Ptch1 is detectable in the ventral spinal cord of Shh-/- embryos. Dbxl protein $(D-F)$ and mRNA expression $(G-I)$ in 15-somite-stage wild-type $(D, G)$, Shh-/- $(E, H)$, and Smo- $-(F, I)$ embryos.

sistent with the absence of ventral p3 pMN and p2 progenitors (Fig. 7D-F; data not shown). Further, Pax6 and Irx3 were present throughout the ventral midline of the spinal cord of Shh and Smo mutant embryos, whereas their expression was absent from that same region in wild-type embryos (data not shown), consistent with altered ventral signaling. Interestingly, Dbxl, which was present in a narrow band of midline cells at the DV boundary in the neural tube of 13-15-somite-stage wildtype embryos, was in a ventrally expanded population of cells in Shh mutants (Fig. 7D,E). In contrast, no Dbx1producing cells were detected in the spinal cords of Smo-/- embryos at a similar axial level (Fig. 7F). Whole mount in situ hybridization of 13-15-somite-stage wildtype and mutant embryos demonstrated some low, discontinuous domains of $D b x 1$ expression in the neural tube of Smo-/- embryos, whereas expression of $D b x 1$ in the neural tube of Shh-/- embryos was continuous and abundant (Fig. 7G-I). Collectively these data suggest the presence of an Shh-independent, Smo-dependent signal in the developing ventral spinal cord and that the complete loss of Hh signaling is accompanied by an initial failure to specify even the most dorsal-ventral progenitor populations.

\section{Gli3 represses $v 0, v 1, v 2$, and $M N s$ in Smo-/- embryos}

Studies of Shh mutants have demonstrated that in the absence of Shh signaling, Gli3-mediated repression is responsible for the reduction of v0, v1, and v2 precursors and the absence of $\mathrm{MN}$ inductions (Litingtung and Chiang 2000). However, as our data indicate, there is residual Smo-dependent Shh-independent signaling in the ventral spinal cord of Shh mutants, and the question of whether removal of Gli3 repression is sufficient for the induction of ventral cell identities in the absence of any $\mathrm{Hh}$ signaling input cannot be resolved. To address the mechanism of Hh action, we examined forelimb sections of the neural tube of Smo-/-;Gli3-/- embryos at $10.5 \mathrm{dpc}$. Removal of Gli3 activity substantially rescued the Smo mutant embryo (data not shown). The neural tube of Smo-/-;Gli3-/- mutant embryos was comparable in size to that of its wild-type littermates. Pax7 showed a normal dorsal restriction in its expression domain (Fig. 8A,B). Dbxl-producing cells were appropriately localized to an intermediate domain that consisted of both a dorsal Dbx $1^{\text {on }} \operatorname{Pax} 7^{\text {on }}$ and a ventral $\mathrm{Dbx} 1^{\text {on }} \mathrm{Pax} 7^{\text {off }}$ progenitor domain, as in wild-type siblings (Fig. 8A,B). Dbx2 appeared to localize to its normal intermediate domain (data not shown). In contrast, Irx3, Pax6, Nkx6.1, and Olig2 were present in cells throughout the ventral half of the neural tube, including the ventral midline (Fig. 8C-F; data not shown). Neither Nkx2.2 nor HNF3 $\beta$ were detected in the spinal cords of Smo-/-;Gli3-/- mutant embryos (Fig. 8C,D,G,H). Together these results suggest that removal of Gli3 inhibition in the complete absence of any Hh signaling is sufficient for the establishment of ventral p0, p1, p2, and $\mathrm{pMN}$ progenitors but not for the induction of $\mathrm{p} 3$ or floor plate identities. Further, the spatial restriction of Dbx1and Dbx2-producing cells suggests that a polarized $\mathrm{Hh}$ signal is not essential for the positioning of $\mathrm{p} 0$ and $\mathrm{p} 1$ progenitors. Analysis of later markers of neural precursors underscores these points. We observed that v0 (Evx1/2) precursors remain tightly clustered near the DV interface of the neural tube as in wild-type embryos, whereas v2 (Chox10) and MN (MNR2) precursors were scattered in a random fashion throughout the ventral half of the neural tube (Fig. 8I-T). v1 (En1) precursors showed an intermediate organization, with most cells 


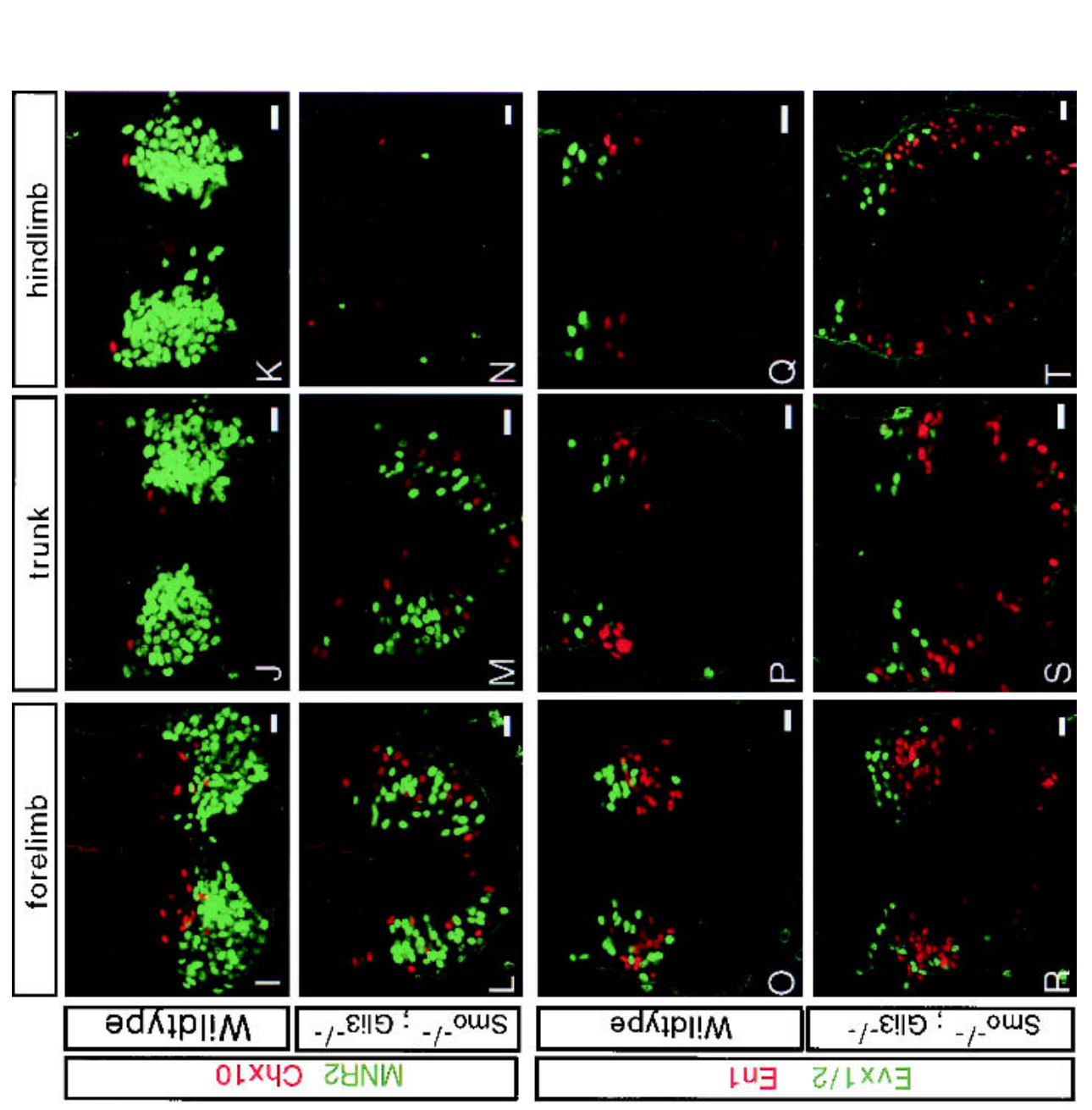

$\frac{1}{6} \cdot \frac{0.00}{0}$

두을

늘

Iत

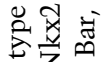

青荡

픙

范

븜

त

$\exists \rtimes$

里 욜

我学

总

록

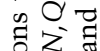

Ho

造

की है

象

要

है च

$1 \approx 0$

ते को

के

प्र

글

콜

ô

总 0 焉

过

정
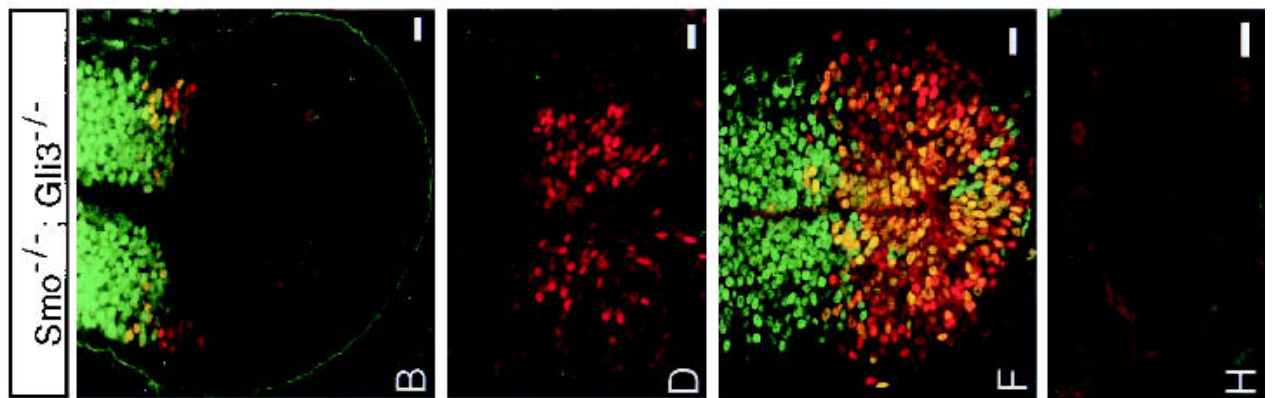

I

के है है

$\infty 0$

守 뭉

च 흥

표으

远交

욜

च है

业之

可运

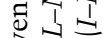

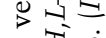

क 政
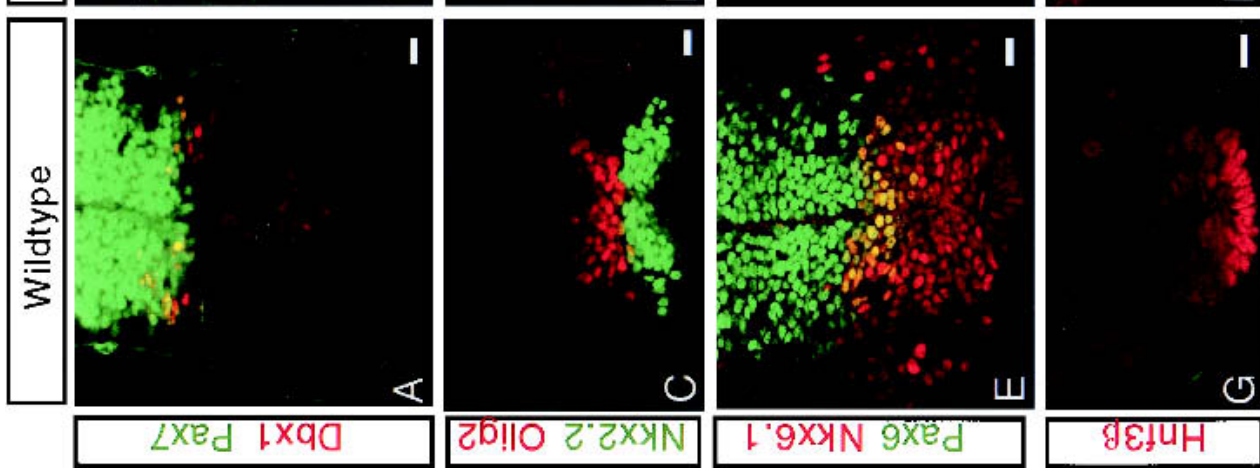

政

o

言要

西

芩

01

궁

넌 근

पू

프

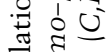

교

《宗

$\infty \frac{\pi}{\alpha} \bar{z}$

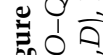

的记 
clustered in close proximity to the v0 precursors as in wild-type embryos but some dispersed throughout the ventral half of the neural tube (Fig. 8O-T). Interestingly, when we compared forelimb, trunk, and hindlimb levels, we observed an increase in the numbers of more ventrally located $\mathrm{v} 1$ precursors at more posterior axial levels that correlated with decreased numbers of both v2 and $\mathrm{MN}$ precursors, indicating an anterior-posterior difference in the requirement for $\mathrm{Hh} / \mathrm{Gli} 3$ interactions in the specification of similar cell identities (Fig. 8I-T).

\section{Discussion}

\section{The range of th signaling}

In this study we examined the behavior of Smo null mutant neural progenitor cells in the developing mammalian spinal cord to better understand the mechanisms by which Hh signaling patterns the neural tube /we refer to Hh signaling to acknowledge the possibility that Ihh might contribute together with Shh in patterning; see below). One question of considerable importance is the actual range of $\mathrm{Hh}$ action. Although all ventral progenitors (p0, p1, p2, pMN, and p3) can be induced by distinct concentrations of Shh in vitro, it is not clear that there is a direct requirement for Hh signaling in the specification of all ventral cell fates. By genetically preventing all $\mathrm{Hh}$ responsiveness in a subpopulation of cells within the putative Hh target field, we show that specification of all ventral progenitors requires Hh signaling in the embryo. Indeed, this requirement actually extends into a domain of Pax7-, Dbx1/2-expressing cells directly above the postulated ventral p0 domain (Briscoe et al. 2001). Although these cells (dorsal p5) had not been thought to produce Evx1/2 neurons (Pierani et al. 1999; Briscoe et al. 2000), which is the most dorsally located ventral interneuron precursor, there is no direct evidence that this is the case. Thus, all $\mathrm{Dbx} 1^{+}$cells, regardless of Pax7 expression, may generate Evx1/2 interneuron precursors, an issue that remains to be resolved.

These general conclusions are in broad agreement with those of Briscoe et al. (2001), who used a quite distinct approach, that is, electroporation into the stage 10 chick spinal cord of an expression construct that produces a mutant form of $\mathrm{Ptch}\left(\mathrm{Ptch}^{\Delta \mathrm{loop}^{2}}\right)$ that can repress Smo but is unable to bind Shh (thereby acting as a dominant inhibitor of Hh signaling in the presence of ligand). Together these two studies establish a direct long-range requirement for Hh signaling in neural tube patterning. What they do not establish is the actual range of action of the signaling process, nor do they address the concentration dependence of Hh signaling.

With respect to the issue of the range of the signaling process in ventral patterning, this depends on knowing when each of the specific progenitor populations is first established in response to a $\mathrm{Hh}$ input and when the maintenance of a given cell fate becomes Hh-independent. Already at the 15-somite stage, at neural tube levels that later give rise to rostral spinal cord regions, there is a well organized ventral pattern with specification of even the most ventral p3, Nkx2.2-producing, progenitor cells (Fig. 8; data not shown; Patten and Placzek 2002). At this axial level, floor plate induction has not occurred; hence the principle source of Shh is the notochord underlying the neural tube. As we demonstrate, Dbx1 induction is Hedgehog-dependent, and Dbx1 is induced in cells that extend 15-20 cell diameters from the ventral midline at the 15-somite stage. That Sh might act over this distance is certainly consistent with the actual distribution of Shh ligand (Incardone et al. 2000; GritliLinde et al. 2001), the transcriptional upregulation of primary targets such as Ptch1 and Glil (Marigo and Tabin 1996; Goodrich et al. 1997, 1999; Pearse et al. 2001), and studies of Shh signaling in other systems such as the vertebrate limb (Lewis et al. 2001; Zeng et al. 2001).

Further, although the data indicate that there is a direct $\mathrm{Hh}$ input for the establishment of all ventral cell identities, they do not address whether Hedgehog action is concentration-dependent. For example, Hedgehog signaling might define a domain of ventral competence, whereas other factors might play a more direct role in the induction of each individual cell fate. Repression of Pax 7 in ventral cells is thought to be a critical first step in the induction of ventral cell identities (Ericson et al. 1996, 1997; Pierani et al. 1999), and the ventral limit of Pax7-expressing cells has long been seen as the limit for Shh signaling. Thus, repression of $\operatorname{Pax} 7$ might define a ventral competence domain. We show here that all Smo-/- cells that lie ventral to the normal ventral limit of $\mathrm{Pax} 7$ expression at $10.5 \mathrm{dpc}$ maintain $\mathrm{Pax} 7$ expression, consistent with there being an absolute requirement for a Hh input to repress $\operatorname{Pax} 7$.

Our results also demonstrate that the presence of v0 and v1 progenitors observed in Shh mutants (Litingtung and Chiang 2000 and data herein) reflects the presence of low-level Hh signaling as indicated by the absence of Pax7 expression and the upregulation of Ptch1 at the ventral midline of the Shh mutant neural tube, where these ventral interneuron precursors arise. As Ihh is expressed in both the node and the gut endoderm that underlies the notochord, we speculate that Ihh signaling is responsible for the limited ventralization in Shh mutants. Interestingly, Shh and Ihh play semiredundant roles in patterning somite domains that lie adjacent to the neural tube (Zhang et al. 2001). Whether Ihh plays any normal role in patterning the ventral neural tube in the context of an active Shh signal is doubtful.

\section{Cell fate specification: Position and identity}

Examining the subsequent fate of Pax7-producing cells provides an insight into the assignment of ventral cell fates in the neural tube. Based on the expression profile of ventral Smo-/- neural progenitor cells (Pax $7^{\circ}$, $\operatorname{Dbx} 1^{\text {on }}, \operatorname{Dbx} 2^{\text {on }}, \operatorname{Irx} 3^{\text {on }}$, and $\left.\operatorname{Pax} 6^{\circ}\right)$ and the neuron types generated by $S m o-/-$ progenitors $\left(\mathrm{Lim} 1 / 2^{\text {on }}\right.$, Pax $2^{\text {on }}$, it appears that many ventral Smo-/- cells adopt a dorsal identity, possibly dorsal p5. However, a few cells also express Evx1/2, indicating that at least some $\mathrm{Smo-}$ - progenitors give rise to v0 precursors. In con- 
trast, as discussed above, Smo-/- cells are unable to generate Dbx-producing neural progenitor cells or v0 precursors where these cells normally arise, in the intermediate domains of the spinal cord. How can these paradoxical results be explained?

One possibility is that $\mathrm{Hh}$ signaling, though required for the specification of a v0 fate, does not directly specify that fate. For example, a Hh signaling input may counteract the inhibitory activity of another signaling pathway that is active at the dorsal-ventral (DV) interface, an inhibitory activity that does not normally extend into the ventral half of the neural tube. The most likely candidates for these presumably dorsal signals would be members of the TGF- $\beta$ superfamily that are responsible for the induction of dorsal neural cell identities. Indeed, the TGF- $\beta$ family members Bmp2, -4 and -7 are potent inhibitors of $\mathrm{Dbx} 1 / 2$ expression and can block the generation of Evx1/2 and En1 interneurons (Pierani et al. 1999). Further, addition of low concentrations of Shh inhibits the expression of BMPs in neural explants in vitro (Pierani et al. 1999). Recent ablation studies using the chick spinal cord indicate that dorsally derived BMP signaling extends into the ventral half of the neural tube at neural groove stages (Patten and Placzek 2002), and it is clear from work here and elsewhere (Briscoe et al. 2001; present paper) that Shh signaling extends into dorsal regions (as defined by Pax7 expression). Thus, it is likely that BMP and Hh signaling overlap in the intermediate region of the spinal cord and that Shh signaling either counteracts or collaborates with the activity of BMPs. Recent studies on the modification of the response of intermediate explants to Shh signaling by BMPs suggest that the former is more likely (Liem et al. 2001). Additional signaling by retinoids may then be required for the specification of v0 fates (Pierani et al. 1999). If so, the production of a retinoid signal would not appear to depend upon the induction of other ventral progenitor populations.

Interestingly, expression of $\mathrm{Ptch}^{\Delta \text { loop2 }}$, which should in principle constitutively repress Smo-activity resembling the phenotype of a Smo-/- mutation, gives a somewhat different result (Briscoe et al. 2001). In that study,

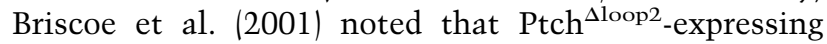
cells not only generate ectopic v0 fates as we observe here, but also v1 and v2 intermediate neuron precursors. The most likely explanation for this different behavior in the two studies is that neural progenitor cells in the ventral spinal cord of chick embryo around the time of electroporation, or shortly after, have been exposed to small amounts of Shh protein, changing their response to a more ventral Pax $7^{\text {off }}$ fate, initiating the specification of ventral progenitors. Alternatively, $\mathrm{Ptch}^{\Delta \mathrm{loop} 2}$ may not be able to suppress all Hh signaling. That Hh signaling has occurred in the chick model is evident by the fact that some ventral transfected cells are Pax $7^{\text {off }}$, whereas all ventral Smo-/- cells are Pax $7^{\text {on }}$. As would be expected,

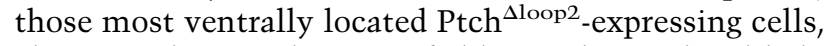
closest to the initial source of Shh signal, were less likely than more dorsally positioned cells to exhibit Pax7 activity (Briscoe et al. 2001). Thus, the timing of transgene expression in relation to the initiation of Hh signal transduction in the chick neural tube is probably the key factor in the different outcomes of the chick and mouse studies.

The analysis of Smo/Gli3 double mutants gives some further insight into the patterning process. Gli3 has no essential role in patterning ventral progenitor regions (Ding et al. 1998; Theil et al. 1999; Litingtung and Chiang 2000; present paper; data not shown), although recent evidence indicates that Gli3 repression regulates the position of dorsal progenitor populations that lie close to the DV boundary (Persson et al. 2002). Whereas Smo mutants are most likely unable to generate any ventral progenitors (as embryos die around $9.0 \mathrm{dpc}$, this cannot be established but the statement is a reasonable reflection of the Smo mutant and Smo chimera analysis herein), the removal of Gli3 activity restores four ventral progenitor populations (p0, p1 p2, and pMN) but not p3 or floor plate fates. Thus, in the absence of any Hh signaling, four Hh-dependent populations are formed on removal of Gli3. Gli3, like its Drosophila counterpart Ci, is known to act as a repressor in the absence of $\mathrm{Hh}$ signaling (Aza-Blanc et al. 1997; Ohlmeyer and Kalderon 1998; Litingtung and Chiang 2000; Wang et al. 2000; Litingtung et al. 2002; Persson et al. 2002). Thus, Hh acts, at least in part, to counteract this repressive activity in the patterning of the ventral neural tube. These data are similar to results obtained in Shh/Gli3 mutants, where residual Hh signaling complicates the interpretation (Litingtung and Chiang 2000). Thus, the restoration of v0, v1, v2, and MN precursors in Smo/Gli3 compound mutants occurs in the absence of an obvious mechanism that replicates the threshold-dependent $\mathrm{Hh}$ signaling that is postulated to govern the positional specification of individual ventral precursor populations. These results indicate that stochastic mechanisms may specify ventral cell fates under certain conditions. Further, this process may vary along the length of the neuraxis, as we observed a progressively more pronounced reduction in v2 interneuron and motorneuron precursors, and a corresponding expansion of $\mathrm{v} 1$ precursors, in more caudal regions of the neural tube. Ventral interneurons differentiate soon after the first motorneurons arise (Jessell and Lumsden 1997), and thus the absence of MNs and abundance of v0 and v1 interneurons at hindlimb levels argues against a timing effect but rather suggests that the observed differences at distinct axial levels are due to positional differences in the patterning process. What accounts for the regional differences is unclear. Further studies will also be required to address whether induction of all ventral fates that are present in the Smo/Gli3 double mutant require the activity of other Gli factors for their specification.

Gli1 mutants have no obvious CNS phenotype (Park et al. 2000). Gli2 is required for induction of the floor plate and normal numbers of ventral p3 progenitors, and for the transcriptional activation of Glil (Ding et al. 1998). Consequently, the Gli1/Gli2 double mutant has an neural tube phenotype identical to that of the Gli2 mutant (Park et al. 2000). The complete absence of both floor 
CNS patterning requires direct hedgehog signaling

plate and p3 progenitors in Smo/Gli3 double mutants is therefore consistent with Hh-mediated activation of Gli2 in the specification of floor plate, but also indicates that an activator form of Gli3 is likely to play a role in the normal induction of $\mathrm{p} 3$ progenitors, an activity that is presumably replaced by Gli2, in Gli3 mutants. Determining whether all ventral progenitors are Gli-dependent will require a detailed analysis of neural tube pattern in Gli2/Gli3 double mutants, where all repressor and activator forms of Gli factors are absent.

\section{Hedgehog signaling is required for segregation of ventral neural precursor domains}

Interestingly, whereas v0 precursors are appropriately positioned in the neural tube of Smo/Gli3 compound mutants, v1, v2, and MN precursors that normally do not overlap now extend over much of the ventral half of the neural tube. Thus, a direct Hh signaling input is required for the normal stratification of ventral progenitor populations within separate domains of the ventral neural tube. This indicates that a central role of the hedgehog-Gli3 signaling axis is to refine the size and position of ventral progenitor pools rather than specifying the individual identity of $\mathrm{MN}, \mathrm{v} 2, \mathrm{v1}$, and v0 precursors. During normal DV patterning, each precursor population forms a sharp boundary with its neighbor, suggesting that there may be some Hh-dependent mechanism that prevents their mixing. In Drosophila, Hh signaling maintains a sharp anterior-posterior (AP) compartment boundary, preventing the mixing of cells at the AP interface (Morata and Lawrence 1975; Blair and Ralston 1997; Rodriquez and Basler 1997). Further, analysis of Smo-/- cells in the abdomen of the fly suggests that a gradient of Hedgehog signaling specifies graded levels of cell affinity (Lawrence et al. 1999a,b). Thus, it is tempting to speculate that $\mathrm{Hh}$ signaling in the mammalian neural tube might regulate the precise separation of precursor domain boundaries along the DV axis through the control of cell affinities.

If a DV gradient of affinities normally contributes to the segregation of progenitors, then dorsalized Smo-/cells in ventral positions might be expected to cluster with each other, minimizing contacts with their ventral neighbors, similar to the behavior of clones of Smo-/clones in the anterior compartment of the fly wing or abdomen (Blair and Ralston 1997; Rodriquez and Basler 1997; Lawrence et al. 1999a,b). In this regard we note that whereas $\mathrm{Smo+} /$ - cells show a fine-grained mosaicism in the neural tube of chimeras, Smo-/- cells tend to cluster in patches, a finding we observe in other $\mathrm{Hh}$ target fields (data not shown). Functionally, modifying differences in cell affinities could prevent cells from mixing freely within a morphogenetic field as cell identities are being specified, a mechanism that may contribute to precision and stability in the induction of different progenitor domains. Presumably, once neurons are generated from progenitor cells their identity is fixed. At this time they may mix "freely" to participate in the formation of appropriate neural circuits.

\section{Materials and methods}

Generation of Smo mutant ES cell lines and chimeras

Mice carrying a Rosa26lacZ allele (Friedrich and Soriano 1991; Zambrowicz et al. 1997) were crossed to mice carrying a Smo null allele (Zhang et al. 2001), and compound heterozygotes were mated to Smo+/- mice. Blastocysts were collected from these matings and ES cell lines generated according to published procedures (Robertson 1987, 1997). All lines were subsequently genotyped by PCR analysis. We obtained three Smo+/-; Rosa16lacz and two Smo-/-;Rosa26 lacZ ES cell lines. ES cells of a given genotype were injected into host (Swiss Webster, Taconic; or C57BL6J, Jackson Laboratories) blastocysts. The blastocysts were transferred into the uterus of a pseudopregnant host at $2.5 \mathrm{dpc}$, and embryos were collected at $10.5 \mathrm{dpc}$ or 11.5 dpc. Chimerism was assessed by histochemical staining of heads from embryos to assess the contribution of $\beta$-galactosidase-producing ES cells prior to analysis of neural tube pattern. All manipulations followed published procedures (Hogan et al. 1994). All clones of a given genotype behaved similarly. In addition, we generated chimeras by direct aggregation of morulae collected from Rosa26lacz;Smo+/- intercrosses with morulae from Swiss Webster (Taconic) or C57BL6J (Jackson Laboratories). Chimerism was assessed as above. The genotype of embryos was determined from fibroblasts arising from outgrowth of tail bud explants grown in the presence of G418. G418 selects for cells carrying the Rosa26lacZ allele ( $\beta \mathrm{Geo})$, and hence for cells derived from the Smo intercross component of the chimera.

\section{Immunohistochemistry and in situ hybridization}

Embryos were fixed at $4^{\circ} \mathrm{C}$ for $30-90 \mathrm{~min}$ in $4 \%$ paraformaldehyde/0.1 M phosphate buffer at $\mathrm{pH} 7.4$, rinsed three times for 10 min in cold PBS, incubated in $30 \%$ sucrose $/ 0.1 \mathrm{M}$ phosphate buffer overnight with an additional change of solution, embedded in tissue-Tek OCT medium (VWR no. 25608-930), and stored at $-80^{\circ} \mathrm{C}$. Immunofluorescent staining of fixed frozen $12-\mu \mathrm{m}$ sections of embryos was performed as described (Yamada et al. 1991), and in situ hybridization was performed essentially as described (Schaeren-Wiemers and Gerfin-Moser 1993). Antibodies were as follows: rabbit $\alpha$ - $\beta$ galactosidase 1:100 (Cappel/ ICN, no. 55976), mouse $\alpha$ - $\beta$ galactosidase 1:1000 (Promega, no. $z 3781$ ), goat $\alpha$ - $\beta$ galactosidase 1:500 (Biogenesis, no. 4600-1409), rabbit $\alpha$-Math1 1:100 (Helms and Johnson 1998), rabbit $\alpha$-ax2 1:200 (BabCo, no. PRB-276P), rabbit $\alpha$-Olig2 1:5000 (H. Takebayashi), rabbit $\alpha$-Nkx6.1 1:3000 (J. Jensen), rabbit $\alpha$-En1 1:100 (A. Joyner), rabbit $\alpha$-HNF3b 1:8000 (Ruiz i Altaba), rabbit $\alpha$-LH2A/B 1:2000 (Liem et al. 1997), rabbit $\alpha$-Is11/2 1:10,000 (Tsuchida et al. 1994, DSHB), rabbit $\alpha$-Dbx1 1:200, rabbit $\alpha$-Dbx2 1:500 (Pierani et al. 1999), guinea pig $\alpha$-LH2B 1:2000, mouse $\alpha$-Evxl/2 1:100, rabbit $\alpha$-Chox10 1:5000, guinea pig $\alpha$-Irx3 1:2500, rabbit $\alpha$-Nkx2.2 1:4000 (T. Jessell, Briscoe et al. $1999,2000,2001)$, mouse $\alpha$-Nkx2.2 1:50, mouse $\alpha$-MNR2/HB9 $1: 20$, mouse $\alpha$-Pax7 1:20, mouse $\alpha$-Pax6 1:20, mouse $\alpha$-Shh $1: 100$ (5E1), mouse $\alpha$-HNF3b 1:100, and mouse $\alpha$-Lim1/2 1:50 (DSHB). Alexa (A) dey-conjugated secondary antibodies (Molecular Probes, A488, A568, A594, and A633) were used to visualize primary antibodies, and images were collected by confocal analysis.

For whole mount in situ hybridization, wild-type and mutant embryos were dissected in PBS, fixed overnight in $4 \%$ paraformaldehyde/PBS at $4^{\circ} \mathrm{C}$, washed several times in ice-cold PBS, transferred through graded steps of increasing concentrations of methanol in $\mathrm{PBS}$, then stored at $-20^{\circ} \mathrm{C}$ prior to use. RNA in situ 
hybridization was performed according to Wilkinson and Nieto (1993).

\section{Acknowledgments}

M.W. was supported by a grant from the "Niels Stensen Foundation", the Netherlands, and a long-term fellowship of the "Human Frontiers Science Program". For the gift of antibodies we thank Jen Jensen (Nkx6.1), Jane Johnson (Math1), Ariel Ruiz I Altaba (Hnf3b), Hirohide Takebayashi (Olig2), Alexandra Joyner (En1), and Tom Jessell (Dbx1 and Dbx2, Nkx2.2, Irx3, LH2AB, LH2B, Evx1, Chox10). Work in A.P.M.'s laboratory was supported by a grant from the NIH (NS 33642).

The publication costs of this article were defrayed in part by payment of page charges. This article must therefore be hereby marked "advertisement" in accordance with 18 USC section 1734 solely to indicate this fact.

\section{References}

Aza-Blanc, P., Ramirez-Weber, F.A., Laget, M.P., Schwartz, C., and Kornberg, T.B. 1997. Proteolysis that is inhibited by hedgehog targets cubitus interruptus protein to the nucleus and converts it to a repressor. Cell 89: 1043-1053.

Blair, S.S. and Ralston, A. 1997. Smoothened-mediated Hedgehog signaling is required for the maintenance of the anteriorposterior lineage restriction in the developing wing of Drosophila. Development 124: 4053-4063.

Briscoe, J., and Ericson, J. 2001. Specification of neuronal fates in the ventral neural tube. Curr. Opin. Neurobiol. 11: 43-49.

Briscoe, J., Sussel, L., Serup, P., Hartigan-O'Connor, D., Jessell, T.M., Rubenstein, J.L.R., and Ericson, J. 1999. Homeobox gene Nkx2.2 and Specification of neuronal identity by graded Sonic hedgehog signaling. Nature 398: 622-627.

Briscoe, J., Pierani, A., Jessell, T.M., Ericson, J. 2000. A homeodomain protein code specifies progenitor cell identity and neuronal fate in the ventral neural tube. Cell 101: 435445.

Briscoe, J., Chen, Y., Jessell, T.M. and Struhl, G. 2001. A Hedgehog-insensitive form of patched provides evidence for direct long-range morphogen activity of sonic hedgehog in the neural tube. Mol. Cell. 7: 1279-1291.

Bumcrot, D.A., Takada, R., and McMahon, A.P. 1995. Proteolytic processing yields two secreted forms of sonic hedgehog. Mol. Cell. Biol. 15: 2294-2303.

Burrill, J.D., Moran, L., Goulding, M.D., and Saueressig, H. 1997. Pax2 is expressed in multiple spinal cord interneurons, including a population of $\mathrm{En}^{+}$interneurons that require Pax6 for their development. Development 124: 4493-4503.

Chamoun, Z., Mann, R., Nellen, D., von Kessler, D., Bellotto, M., Beachy, P., and Basler, K. 2001. Skinny hedgehog, an acyltransferase required for palmitoylation and activity of the secreted Hedgehog protein signal. Science 293: 20802084.

Denef, N., Neubuser, D., Perez, L., and Cohen, S.M. 2000. Hedgehog induces opposite changes in turnover and subcellular localization of patched and smoothened. Cell 102: 521531.

Ding, Q., Motoyama, J., Gasca, S., Mo, R., Sasaki, H., Rossant, J., and Hui, C.C. 1998. Diminished Sonic Hedgehog signaling and lack of floor plate differentiation in Gli2 mutant mice. Development 125: 2533-2543.

Echelard, Y., Epstein, D.J., St-Jacques, B., Shen, L., Mohler, J.,
McMahon, J.A., and McMahon, A.P. 1993. Sonic hedgehog, a member of a family of putative signaling molecules, is implicated in the regulation of CNS polarity. Cell 75: 14171430.

Eggenschwiler, J., Espinoza, E., and Anderson, K. 2001. Rab23 is an essential negative regulator of the mouse Sonic hedgehog signaling pathway. Nature 412: 194-198.

Ericson, J., Morton, S., Kawakami, A., Roelink, H. and Jessell, T.M. 1996. Two critical periods of sonic hedgehog signaling required for the specification of motor neuron identity. Cell 87: 661-673.

Ericson, J., Rashbass, P., Schedl, A., Brenner-Morton, S., Kawakami, A., van Heyningen, V., Jessell, T.M., and Briscoe, J. 1997. Pax6 controls progenitor cell identity and neuronal fate in response to graded Shh signaling Cell 90: 169-180.

Friedrich, G. and Soriano, P. 1991. Promoter traps in embryonic stem cells: A genetic screen to identify and mutate developmental genes in mice. Genes \& Dev. 5: 1513-1523.

Fu, H., Qi, Y., Tan, M., Cai, J., Takebayashi, H., Nakafuku, M., Richardson, W., and Qui, M. 2002. Dual origin of spinal oligodendrocyte progenitors and evidence for the cooperative role of Olig2 an Nkx2.2 in the control of oligodendrocyte differentiation. Development 129: 681-693.

Goodrich, L.V., Johnson, R.L., Milenkovic, L., McMahon, J., and Scott, M.P. 1996. Conservation of the hedgehog/patched signaling pathway from flies to mice: Induction of mouse Patched gene by hedgehog. Genes \& Dev. 10: 301-312.

Goodrich, L.V., Milenkovic, L., Higgins, K.M., and Scott, M.P. 1997. Altered neural cell fates and medulloblastoma in mouse patched mutants. Science 277: 1109-1113.

Goodrich, L.V., Jung, D., Higgins, K.M., and Scott, M.P. 1999. Overexpression of Ptcl inhibits induction of Shh target genes and prevents normal patterning in the neural tube. Dev. Biol. 211: 323-334.

Gritli-Linde, A., Lewis, P., McMahon, A., and Linde, A. 2001. The whereabouts of a morphogen: Direct evidence for short and graded long-range activity of hedgehog signaling peptides. Dev. Biol. 236: 364-386.

Hahn, H., Wojnowski, L., and Miller, G. 1999. The patched signaling pathway in tumorigenesis and development: Lessons from animal models. J. Mol. Med. 77: 459-468.

Hatini, V. and S. Dinardio. 2001. Divide and conquer: Pattern formation in Drosophila embryonic epidermis. TIG 17: 574-579.

Helms, A.W. and Johnson, J.E. 1998. Progenitors of dorsal commissural interneurons are defined by mATH1 expression. Development 125: 919-928.

Hogan, B., Beddington, R., Constatini, F., and Lacy, E. 1994. Manipulating the mouse embryo. A laboratory manual. 2nd ed. Cold Spring Harbor Laboratory Press, Cold Spring Harbor, NY.

Incardone, J.P., Lee, J.H., Robertson, C.P., Enga, K., Kapu, R.P., and Roelink, H. 2000. Receptor-mediated endocytosis of soluble and membrane-tethered Sonic hedgehog by Patched1. Proc. Natl. Acad. Sci. USA 97: 12044-12049.

Ingham, P.W. and McMahon, A.P. 2001. Hedgehog signaling in animal development: Paradigms and principles. Genes \& Dev. 15: 3059-3087.

Ingham, P.W., Nystedt, S., Nakano, Y., Brown, W., Starh, D., van den Heuvel, M., and Taylor, A.M. 2000. Patched represses the hedgehog signaling pathway by promoting modification of the smoothened protein. Curr. Biol. 10: 13151318.

Jessell, T.M. 2000. Neuronal specification in the spinal cord: Inductive signals and transcriptional codes. Nat. Rev. Genet. 1: 20-29.

Jessell, T.M. and Lumsden, A. 1997. Inductive signals and the 
assignment of cell fate in the spinal cord and hindbrain. In Molecular and cellular approaches to neural development, (eds. W.M. Cowan et al.), pp. 290-333. Oxford University Press, New York, NY.

Lawrence, P.A., Casal, J., and Struhl, G. 1999a. Hedgehog and engrailed: Pattern formation and polarity in the Drosophila abdomen. Development 126: 2431-2439.

- 1999b. The Hedgehog morphogen and gradients of cell affinity in the abdomen of Drosophila. Development 126: 2441-2449.

Lee, J.J., Ekker, S.C., von Kessler, D.P., Porter, J.A., Sun, B.I., and Beachy, P.A. 1994. Autoproteolysis in hedgehog protein biogenesis. Science 266: 1528-1537.

Lee, J.K. and Jessell, T.M. 1999. The specification of dorsal cell fates in the vertebrate central nervous system. Ann. Rev. Neurosci. 22: 261-294.

Lewis, P., Dunn, M., McMahon, J., Logan, M., Martin, J., StJacques, B., and McMahon, A.P. 2001. Cholesterol modification of sonic hedgehog is required for long-range signaling activity and effective modulation of signaling by Ptc1. Cell 105: 599-612.

Liem, K.F., Tremml, G., and Jessell, T.M. 1997. A role for the roof plate and its resident $\mathrm{TGFb}$-related proteins in neuronal patterning in the dorsal spinal cord. Cell 91: 127-138.

Liem, K.F., Jessell, T.M., and Briscoe, J. 2000. Regulation of the patterning activity of Sonic hedgehog by secreted BMP inhibitors expressed by notochord and somites. Development 127: 4855-4866.

Litingtung, Y. and Chiang, C. 2000. Specification of ventral neuron types is mediated by an antagonistic interaction between Shh and Gli3. Nat. Neurosci. 3: 979-985.

Litingtung, Y., Dahn, R.D., Li, Y., Fallon, J.F., and Chiang, C. 2002. Shh and Gli3 are dispensable for limb skeleton formation but regulate digit number and identity. Nature 418: 979-983.

Marigo, V. and Tabin, C. 1996. Regulation of Patched by Sonic hedgehog in the developing neural tube. Proc Natl. Acad. Sci. USA 93: 9346-9351.

Marigo, V., Davey, R.A., Zuo, Y., Cunningham, J.M., and Tabin, C.J. 1996. Biochemical evidence that patched is the Hedgehog receptor. Nature 384: 176-179.

McMahon, A.P., Ingham, P.W., and Tabin C. 2002. The developmental roles and clinical significance of Hedgehog signaling. Current Topics in Developmental Biology (In press).

Ming, J.E., Roessler, E., and Muenke, M. 1998. Human developmental disorders and the Sonic hedgehog pathway. Mol. Med. Today 4: 343-349.

Morata, G. and Lawrence, P.A. 1975. Control of compartment development by the engrailed gene in Drosophila. Nature 255: 614-617.

Ohlmeyer, J. and Kalderon, D. 1998. Hedgehog stimulates maturation of Cubitus interruptus into a labile transcriptional activator. Nature 396: 749-753.

Park, H.L., Bai, C., Platt, K.A., Matise, M.P., Beeghly, A., Hui, C.C., Nakashima, M., and Joyner, A.L. 2000. Mouse Gli1 mutants are viable but have defects in Shh signaling in combination with Gli2 mutation. Development 127: 1593-1605.

Patten, I. and Placzek, M. 2002. Opponent activities of Shh and BMP signaling during floor plate induction in vivo. Curr. Biol. 12: 47-52.

Pearse, R.V., Vogan, K.J., and Tabin, C.J. 2001. Ptc1 and Ptc2 transcripts provide distinct readouts of hedgehog signaling activity during chick embryogenesis. Dev. Biol. 239: 15-29.

Pepinsky,R., Zeng, C., Wen, D., Rayhorn, P., Baker, D., Williams, K., Bixler, S., Ambrose, C., Garber, E., Miatkowski, K., et al. 1998. Identification of a palmitic acid-modified form of human Sonic hedgehog. J. Biol. Chem. 273: 1403714045.

Persson, M., Stamataki, D., te Welscher, P., Andersson, E., Böse, J., Rüther U., Ericson, J., and Briscoe, J. 2002. Dorsal-ventral patterning of the spinal cord requires Gli3 transcriptional repressor activity. Genes \& Dev. (this issue)

Pierani, A., Brenner-Morton, S., Chiang, C., and Jessell, T.M. 1999. A Sonic hedgehog-independent, retinoid-activated pathway of neurogenesis in the ventral spinal cord. Cell 97: 903-915.

Porter, J.A., von Kessler, D.P., Ekker, S.C., Young, K.E., Lee, J.J., Moses, K., and Beachy, P.A. 1995. The product of hedgehog autoproteolytic cleavage active in local and long-range signaling. Nature 374: 363-366.

Porter, J.A., Ekker, S.C., Park, W.J., von Kessler, D.P., Young, K.E., Chen, C.H., Ma, Y., Woods, A.S., Cotter, R.J., Koonin, E.V., et al. 1996a. Hedgehog patterning activity: Role of a lipophilic modification mediated by the carboxy-terminal autoprocessing domain. Cell 86: 21-34.

Porter, J.A., Young, K.E., and Beachy, P.A. 1996b. Cholesterol modification of hedgehog signaling proteins in animal development. Science 274: 255-259.

Rietveld, A., Neutz, S., Simons, K., and Eaton, S. 1999. Association of sterol- and glycosylphosphatidylinositol-linked proteins with Drosophila raft lipid microdomains. J. Biol. Chem. 274: 12049-12054.

Robertson, E.J. 1987. Teratocarcinomas and embryonic stem cells: A practical approach. pp. 71-112. IRL Press, Oxford, UK.

Robertson, E.J. 1997. Derivation and maintenance of embryonic stem cell cultures. Methods Mol. Biol. 75: 173-184.

Rodriguez, I. and Basler, K. 1997. Control of compartmental affinity boundaries by Hedgehog. Nature 389: 614-618.

Sander, M., Paydar, S., Ericson, J., Briscoe, J., Berber, E., German, M., Jessell, T.M., and Rubenstein, J.L.R. 2000. Ventral neural patterning by Nkx homeobox genes: Nkx6.1 controls somatic motor neuron and ventral interneuron fates. Genes \& Dev. 14: 2134-2139.

Schaeren-Wiemers, N. and Gerfin-Moser, A. 1993. A single protocol to detect transcripts of various types and expression levels in neural tissue and cultured cells: In situ hybridization using digoxigenin labeled cRNA probes. Histochemistry 100: 431-440.

Stone, D.M., Hynes, M., Armanini, M., Swanson, T.A., Gu, Q., Johnson, R.L., Scott, M.P., Pennica, D., Goddard, A., Philips, H., et al. 1996. The tumour-suppressor gene Patched encodes a candidate receptor for Sonic hedgehog. Nature 384: 129134.

Strutt, H., Thomas, C., Nakano, Y., Stark, D., Neave, B., Taylor, A.M., and Ingham, P.W. 2001. Mutations in the sterol-sensing domain of Patched suggest a role for vesicular trafficking in smoothened regulation. Curr. Biol. 11: 608-613.

Theil, T., Alvarez-Bolado, G., Walter, A., and Ruther, U. 1999. Gli3 is required for Emx gene expression during dorsal telencephalon development. Development 126: 3561-3571.

Tsuchida, T.M., Ensini, S.B., Morton, S.B., Baldassare, M., Edlund, T., Jessell, T.M., and Pfaff, S.L. 1994. Topographic organization of embryonic motor neurons defined by expression of LIM homeobox genes. Cell 79: 957-970.

Wang, B., Fallon, J.F., and Beachy, P.A. 2000. Hedgehog-regulated processing of Gli3 produces an anterior/posterior repressor gradient in the developing vertebrate limb. Cell 100: 423-434.

Wilkinson, D.G. and Nieto, M.A. 1993. Detection of messenger RNA by in situ hybridization to tissue sections and whole mounts. Methods Enzymol. 225: 361-373. 
Wijgerde et al.

Yamada, T., Placzek, M., Tanaka, H., Dodd, J., and Jessell, T.M. 1991. Control of cell pattern in the developing nervous system: Polarizing activity of the floor plate and notochord. Cell 64: 635-647.

Zambrowicz, B.P., Imamoto, A., Fiering, S., Herzenberg, L.A., Kerr, W.G., and Soriano, P. 1997. Disruption of overlapping transcripts in the Rosa bgeo 26 gene trap strain leads to widespread expression of b-galactosidase in mouse embryos and hematopoietic cells. Proc. Natl. Acad. Sci. USA 94: 37893794.

Zeng, X., Goetz, J., Suber, L., Scott, W.J., Schreiner, C., and Robbins, D. 2001. A freely diffusible form of Sonic hedgehog mediates long-range signaling. Nature 411: 716-720.

Zhang, X.M., Ramalho-Santos, M., and McMahon, A.P. 2001. Smoothened mutants reveal redundant roles for Shh and Ihh signaling including regulation of $\mathrm{L} / \mathrm{R}$ asymmetry by the mouse node. Cell 105: 781-792. 


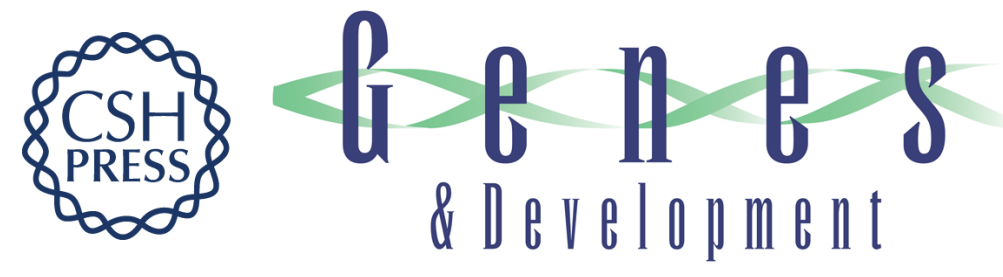

\section{A direct requirement for Hedgehog signaling for normal specification of all ventral progenitor domains in the presumptive mammalian spinal cord}

Mark Wijgerde, Jill A. McMahon, Michael Rule, et al.

Genes Dev. 2002, 16:

Access the most recent version at doi:10.1101/gad.1025702

References This article cites 63 articles, 24 of which can be accessed free at:

http://genesdev.cshlp.org/content/16/22/2849.full.html\#ref-list-1

License

Email Alerting Receive free email alerts when new articles cite this article - sign up in the box at the top

Service right corner of the article or click here.

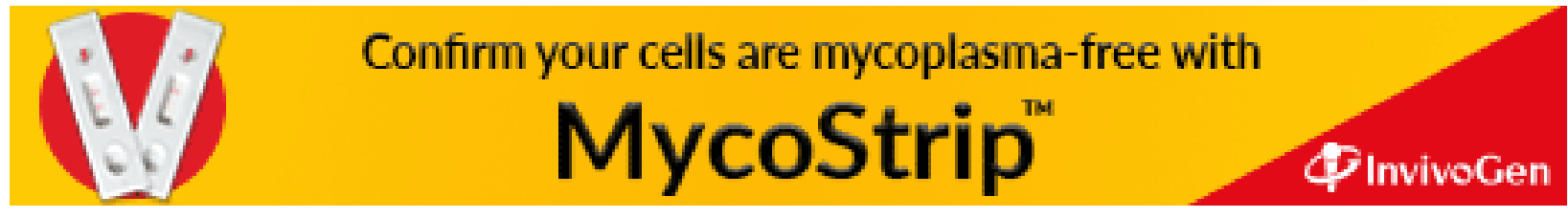

